\title{
Towards Tourism Sustainability: General Aspects and Empirical Evidence of the Italian Experience at Decentralized Level, with Specific Reference to Sicily
}

\author{
Silvana Cassar \\ Salvo Creaco \\ Department of Economics and Business, \\ University of Catania \\ Corso Italia 55 , \\ Catania 95129, Italy \\ E-mail: scassar@unict.it \\ E-mail: creaco@unict.it
}

Abstract: Even though the concepts and observations underlying sustainability are not a novelty, sustainable development was given impetus and made popular in 1987 by the Brundtland Report. This report introduced development policies and strategies that acknowledged the importance of resource and environmental constraints and the limitations imposed on growth patterns. Although sustainable development proved difficult to define and make operative, the concept was progressively applied to those economic sectors which had major detrimental effects on income, employment and wealth. Sustainable tourism was effectively one part of the effort to take full account of the current and future economic, social and environmental impacts of the sector, addressing the needs of visitors, industry, environment and host communities. After reviewing the main questions referring to the environmental, economic and social aspects of tourism development, this paper tries to identify a balanced indicator showing the impact of tourist accommodation facilities and related infrastructure in Sicily in terms of the three fundamental pillars of sustainability. Based on this indicator, the ranking of the nine Sicilian provinces is provided. In a wider perspective, the proposed approach is applied to make a comparison of tourism sustainability in Sicily and in other Italian regions.

Keywords:accommodation facilities, sustainable tourism development, sustainability, tourism industry 


\section{Towards tourism sustainability}

Starting around 1960, the rebirth of environmentalism caused economists and other analysts to look afresh at the central question regarding the incompatibility of economic growth and concern for the natural environment. It was against this scenario that different environmental ideologies flourished and environmental economics became a sub-discipline of modern neoclassical thinking. In this context, Turner (1993) makes a clear distinction between four basic ideologies:

- extreme cornucopian technocentrism: a resource exploitive, growth-oriented position;

- accommodating technocentrism: a resource conservationist and managerial position;

- communalist ecocentrism: a resource preservationist position;

- extreme ecocentrism: an extreme preservationist position supported by an acceptance of bioethics.

The theoretical insight that society might actually be better through government policies that respect natural and environmental resources suggested a potentially important line of investigation and a possible guideline for long-run economic measures. In this direction, the literature on environmental economics was massive. The concepts and observations underlying sustainability are thus not a novelty (Barbier, 1998; Heal, 1998). Previously expressed by the Declaration of the United Nations Conference on the Human Environment (UN, 1972) and the provocative report The Limits to Growth by the Club of Rome which highlighted the imminent threat of "overshot" (Meadows et al., 1972), they were outlined in the middle of the 1970s by the Bariloche model (Herrera, 1974; Herrera, Scolnik \& Chichilnisky, 1976; Chichilnisky, 1977a) aimed at examining "alternative feasible growth paths and alternative criteria of economic efficiency, and to compare economic performance according to different measures" with the aim of giving a "possible mathematical formalization of economic efficiency in an economy concerned with attaining levels of per capita consumption of basic goods, subject to economic and social welfare constraints" (Chichilnisky, 1977b, p. 290). In this direction, theoretical environmentalists argued that the intellectual roots of sustainability could be traced back to the term 'stationary' or 'steady-state economy' used by the nineteenth-century political economists to refer to a balance between production and natural resources implying equality of access to natural resources for future generations (Blaug, 1978; Bresso, 1982; 1993; Musu, 1993; Pearce, 2002; Grafton et al., 2004; Ciani Scarnicci et al., 2014; Sandmo, 2014). 
In the years that followed, the term sustainability appeared in a range of contexts, most prominently in the World Conservation Strategy, the manifesto published collectively in 1980 by the World Conservation Union (IUCN), the United Nations Environment Programme (UNEP), and the World Wide Fund for Nature (WWF), whose main aim was to help the achievement of sustainable development at global level thorough the conservation of living resources. In particular, the Strategy, as a product of an extremely through consultation process, reflected a compromise: "among conservationists, who may differ on the relative importance of particular ecosystems, species, issues and measures, and between conservationists and the practitioners of development, who may differ in their emphasis on maintenance on the one hand and production on the other" (IUCN, UNEP \& WWF, 1980, p. ii). At the same time, the US Global Report (Barney, 1980) was the first global environmental/developmental study prepared by a national government. This study, based on the integration of a number of sector-specific projections, appeared to confirm negative perspectives about the consequences of the neglect of the common interest and the over-exploitation of open-access resources (Pearce \& Turner, 1990, p. 23). Sustainability was given further impetus a few years later by the Brundtland Commission's report, Our Common Future, which described sustainable development as "a development that meets the needs of the present without compromising the ability of future generations to meet their own needs"; and "a process of change in which the exploitation of resources, the directions of investments, the orientation of technological development and institutional changes are made consistent with future as well present needs" (World Commission on Environment and Development, 1987, p. 8).

These global analyses had many aspects in common to their underlying visions of sustainability. Particularly, the Bariloche model and the Brundtland report shared two important elements. One was the exigency that the decision-making process should adopt development policies compatible with the planet's endowments, so recognizing, from an economic perspective, the relevance of resource and environmental constraints and the limitations that they may determine on growth patterns. The second was the strong emphasis placed on equity, both within and between generations, so implying that only the egalitarian satisfaction of material and cultural basic needs and a dignified and active participation of all individuals in social decisions were the indispensable prerequisite for full access to all higher forms of human activity (Beltratti, Chichilnisky \& Heal, 1993).

The 1980s thus witnessed a fundamental change in the way governments and development agencies thought about the relation between economic efficiency, equity and living resource conservation, and sustainability was progressively 
accepted by policy-oriented institutions, acting not only at international level but at national and local scale as well. ${ }^{1}$ However, a clear interpretation of the concept was still lacking in many analyses providing policy guidance on how the three fundamental objectives of sustainability could be reconciled, since discussion of sustainability was "mainly an occasion for the expression of emotions and attitudes" (Solow, 1993, p. 167). As an outcome, "endless streams of academics and diplomats could spend many comfortable hours trying to define it without success" (O'Riordan, 1993, p. 37). ${ }^{2}$ But if the wide-ranging discussion of different interpretations of sustainability in the 1980s was characterized by definitional confusion and a lack of precision, many important steps were, however, taken towards drawing out the operational implications of the concept, the precise identification of its critical dimensions and the necessary link between them. In this vein of investigation, the core pillars of sustainability-economy, ecology, and equity - were regarded as the vertices of a triangle; the interaction between ecology and economy, and economy and equity, respectively, was seen as the basic issue in any sustainable development discussion, and the integration of the three corresponding disciplines could be used as a sound framework to guarantee the long-term growth of policies and strategies (Sirageldin, 1994). This view, based on the World Bank's approach to the issue (Dixon \& Steer, 1994), can be alternatively expressed showing the interaction of the core pillars of sustainable development through a three-circles model. This interaction is formed by the overlapping of the three circles representing economic, social and environmental concerns respectively (Fig. 1). Following this interpretation of sustainability, a double advantage arises: the concept is easy to understand for a wide range of stakeholders and is particularly useful in explaining how the concept itself could be applicable to different scales (international, national and local).

For instance, at international level, the concept of sustainability was given the status of a global mission by the United Nations Conference on Environment and Development held in 1992. In the same year, at supranational level, the European Community in its Fifth Environmental Action Programme described the challenge of the 1990s in terms of the need for a far-sighted, cohesive and effective approach to achieve a sustainable development; in this sense, in the Programme the term sustainable reflected "a policy and strategy for continued economic and social development without detriment to the environment and the natural resources on the quality of which continued human activity and further development depend" (EC, 1992, p. 12).

2 At the end of the 1980s, Pezzey (1989) listed a collection of fifty sustainability definitions. About a decade later, Pezzey (1997) pointed out the existence of about five thousand definitions that one could readily find in the prevailing literature on this issue. 
Figure 1. The three-circles model of sustainability

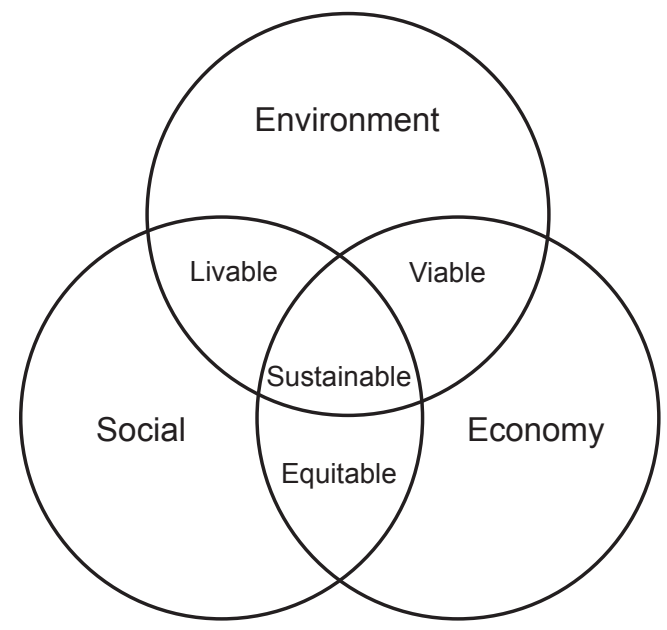

Source: Tanguay, Rajaonson \& Therrien, 2011, p. 3

The emergence of this large and variegated literature concerned with the general concept of sustainable development and its operational implications were followed by extensive research to analyze the natural resource depletion and environmental degradation associated with the economic sectors that had major effects on income, employment and wealth. Sustainable tourism was effectively one part of the effort to achieve economic development, employment and poverty reduction without destroying culture and damaging the environment of host communities. ${ }^{3}$ As with other sub-fields of the sustainable development literature, sustainable tourism was also far from being consistently defined. Despite the difficulties to express the concept in a univocal manner, that is, whether the term should be interpreted as a process of tourism development and/ or a result of tourism development (Berno \& Bricker, 2001; Liu, 2003; Buckley, 2012), a first general definition was, however, widely accepted. In 1998, the World Tourism Organization (WTO) viewed as sustainable tourism which

meets the needs of present tourists, host regions while protecting and enhancing opportunity for the future. It is envisaged as leading to management of all resources in such a way that economic, social and aesthetic needs can be fulfilled while maintaining cultural integrity, essential ecological processes, biological diversity and life support systems. Sustainable tourism products are products which

3 The shift towards sustainability in tourism was evident with the publication of the Journal of Sustainable Tourism in 1993. 
are operated in harmony with the local environment, community and cultures so that these become the beneficiaries not the victims of tourism development (WTO, 1998, p. 20).

This definition, obviously underpinned by environmental, economic and social benefits was, however "widely flexible to allow a variety of approaches and interpretations of the concept" (Cernat \& Gourdon, 2007, p. 1), ${ }^{4}$ so to lead some tourism theorists and practitioners to question its fruitfulness (Middleton \& Hawkins, 1998; Weaver \& Lawton, 1999; Sharpley, 2000).

Since tourism was increasingly gaining relevance in the socio-economic growth literature as a recognized tool for achieving sustainable development, especially in developing countries (Diaz, 2001), tourism sustainability became the major focus of several specialized agencies. It also evolved notably through Agenda 21, the plan of action which emerged from the UN Conference on Environment (popularly known as The Heart Summit), held at Rio de Janeiro in 1992 (Shah, McHarry \& Gardiner, 2002) and the subsequent plan of implementation from the World Summit on Sustainable Development, held at Johannesburg in 2002 (UN, 2002). The principles established in the Rio Declaration served as the basis for the progressive redefinition of the sustainable tourism concept, which was generally expressed as "tourism that takes full account of its current and future economic, social and environmental impacts, addressing the needs of visitors, the industry, the environment and host communities" (UNEP \& UWTO, 2005, p. 12).

The importance of tourism to sustainable development and the need for tourism to integrate sustainability principles was further increasingly recognized in subsequent international fora, and with echoes in policy statement, also acquiring a relevant position both in academic analyses of tourism and management recommendations (Fossati \& Panella, 2000; Yazdi, 2012; Alvarez, 2014). Particularly, tourism theorists and practitioners pointed out two directions in which tourism policy could exert an influence: minimizing the adverse social and environmental effects on host communities; and maximizing tourism's positive impact on local economies, the conservation of natural and cultural heritage, and the quality of life of hosts and visitors. This issue was reflected in the proliferation of sustainable tourism policy statements and operational guidelines, all recalling the exigency that principles and normative prescriptions should always lead to a suitable balance between the three dimensions of

4 For instance, in its 1999 annotated bibliography, the WTO reviewed 96 books and 280 articles and papers dealing with sustainable tourism topics and issues, all characterized by a rather wide diversity of approaches (WTO, 1999). 
sustainability and long-term growth of the hospitality industry (Cobbinah, Black \& Thwaites, 2013) $)^{5}$. In order to put this exigency into practice, the UNEP together with the UNWTO developed a set of twelve aims addressing economic, environmental and social impacts of tourism. Many of these aims are related to a single pillar of sustainability whilst others refer to a combination of issues and impacts, so recognizing that these aims are interdependent but could be both mutually reinforcing or in competition (UNEP \& UNWTO, 2005). Figure 2 captures this view by applying to the tourism industry the essence of the three circles-model on which the general concept of sustainability is founded while Box 1 points out the objectives of each dimension of tourism sustainability.

Figure 2. Pillars and aims of tourism sustainability

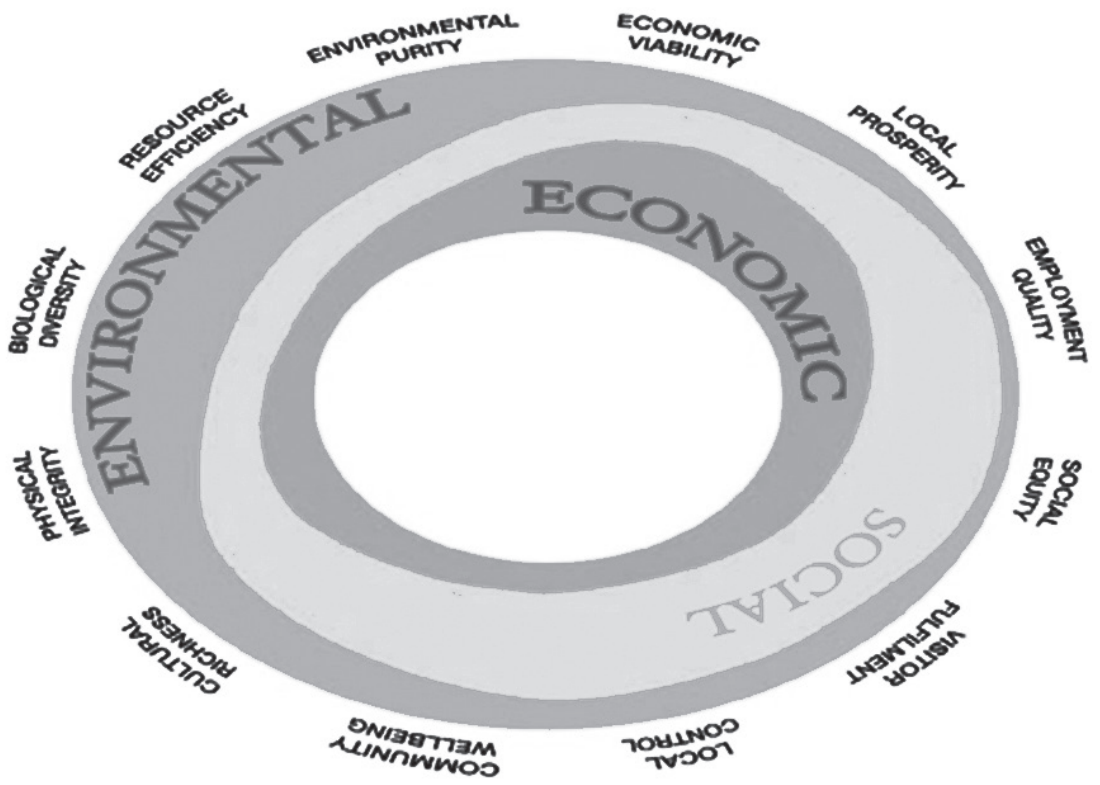

Source: UNEP \& UNWTO, 2005, p. 20

$5 \quad$ Theoretical and empirical analyses that cover several issues on tourism sustainability are provided by Cerina, Markandya and McAleer (2010). 


\section{Box 1. Objectives of each pillar of tourism sustainability}
1. Economic prosperity
a. To ensure the long-term competitiveness, viability and prosperity of tourism enterprises and destinations.

b. To provide quality employment opportunities, offering fair pay and conditions for all employees and avoiding all forms of discrimination.

\section{Social equity and cohesion}

a. To enhance the quality of life of local communities through tourism, and engage them in its planning and management

b. To provide a safe, satisfying and fulfilling experience for visitors, available to all without discrimination by gender, race, religion, disability or in other ways.

\section{Environmental and cultural protection}

a. To minimize pollution and degradation of the global and local environment and the use of scarce resources by tourism activities.

b. To maintain and strengthen cultural richness and biodiversity and contribute to their appreciation and conservation.

Source: Tourism Sustainability Group, 2007, p. 3

When each dimension of tourism sustainability is expressed on the basis of some quantitative and qualitative indicators, a unified evaluation process enables the estimate of the changes in the course of tourism management and implementation. ${ }^{6}$ In this process, an ex ante appraisal guarantees that a proposed initiative will be sustainable in the long run from economic, social and environmental perspective. An ongoing appraisal (itinere evaluation), carried out concurrently with the implementation, in a fixed time, will allow a remodulation of the activity through the critical consideration of the first results obtained through the related expenditure. An ex post evaluation, carried out a certain length of time after the conclusion of the initiative, will verify the impact effectively achieved by the intervention compared to the overall objectives and

$6 \quad$ Indicators for sustainable tourism development are a relatively new field of research and analysis. WTO has been promoting the use of sustainable tourism indicators since the early 1990s, as essential instruments for policy-making planning and management processes at destinations (WTO, 1993; 1997). The result of this vein of investigation was the publication, in 2004, of The Guidebook on Indicators of Sustainable Development for Tourism (WTO, 2004), which was the most comprehensive study on this issue at that time. 
project purpose, also allowing to illustrate the inconsistencies in the objectives initially fixed.

Figure 3. Links between tourism projects and sustainable development

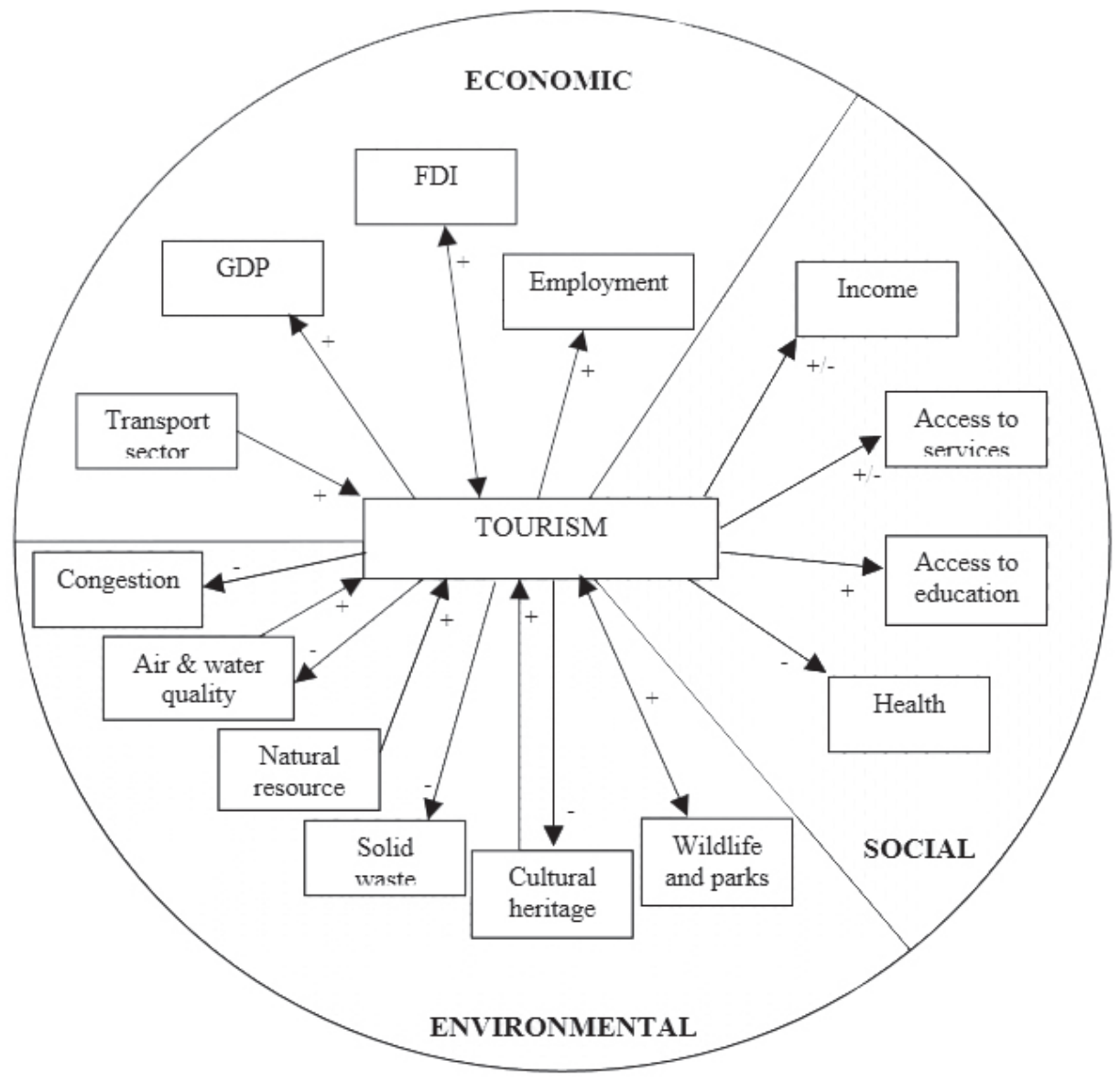

Source: Markandya, Taylor \& Pedroso, 2003, p. 3

Obviously, the possibility to identify indicators that are policy-relevant will depend on the comprehension of the exhaustive typology of the impacts of the tourism project and the projects' effects on sustainable development (WTO, 1993; 1997; Manning, 1999; Yunis, 2004; Choi \& Sirakaya, 2006; UNWTO, 2006). In this direction, an important contribution has been provided by how the World Bank has treated tourism in its development strategy and in its lending and other activities as a consequence of the inclusion of the sector in a number of projects to be financed. The findings of the World Bank's research on the 
key linkages between tourism and development are reported in Figure 3, which shows how projects of a wide set of economic sectors, including transport, health and cultural heritage, have impacts on, and are likewise affected by tourism development. Figure identifies the impacts which have positive influence (+), or negative effect (-) and also highlights the essential links that the prevailing literature has identified on this question, being the direction of the relationship indicated by arrows (Markandya, Taylor \& Pedroso, 2003, p. 2). This framework will apply to any level of decision-making (public and private), since it allows governments and other relevant stakeholders (mainly tourism enterprises) to develop strategies, policies and tools to maximize tourism's positive effects while minimizing the adverse impacts of hospitality industry.

\section{Sustainable tourism in Sicily}

The theoretical and practical framework that has been sketched here makes it possible to analyze the essential aspects of tourism sustainability in Sicily. The decision to refer to this region as a trail-blazer for tourism sustainability at decentralized level is not incidental. Effectively, the proposed analysis is part of wider research aimed at pointing out the development that tourism in the region has registered as a consequence of public intervention progressively implemented in Italy since the 1920s. ${ }^{7}$ Some information of an administrative nature represents an indispensable premise to our analysis.

7 The first step of this wider research is represented by the analysis of tourism development in Sicily during the Fascist period (1922-1943). Next, the analysis has examined Sicilian tourism development since the 1950s, after the end of the Second World War, when the Italian southern regions were the object of a particular policy called "extraordinary intervention for the South" aimed at stimulating the economic and industrial development of their territories to overcome the dual nature of the national economy, the same dichotomy that earlier administrative and economic measures had failed to resolve satisfactorily. Particularly, the effects of this regional policy in tourism development were examined making reference both to the years 1950-1986, in which the extraordinary intervention was implemented through the Fund for the South (Cassa per il Mezzogiorno), a decentralized government Agency, and the period in which the regional policy was carried out by means of a new centralized system foreseeing the abolition of the Cassa (1986-1992) and the introduction of a more general mechanism in favour of all depressed areas of the country. The final part of this wider research embraces the same period in which sustainability and sustainable development were give impetus and made popular. The main results of these fields of investigation are expressed by Cassar (2007; 2015a; 2015b), Creaco (2015a; 2015b) and Cassar \& Creaco (2012). 
Figure 4. Sicily and its administrative subdivision

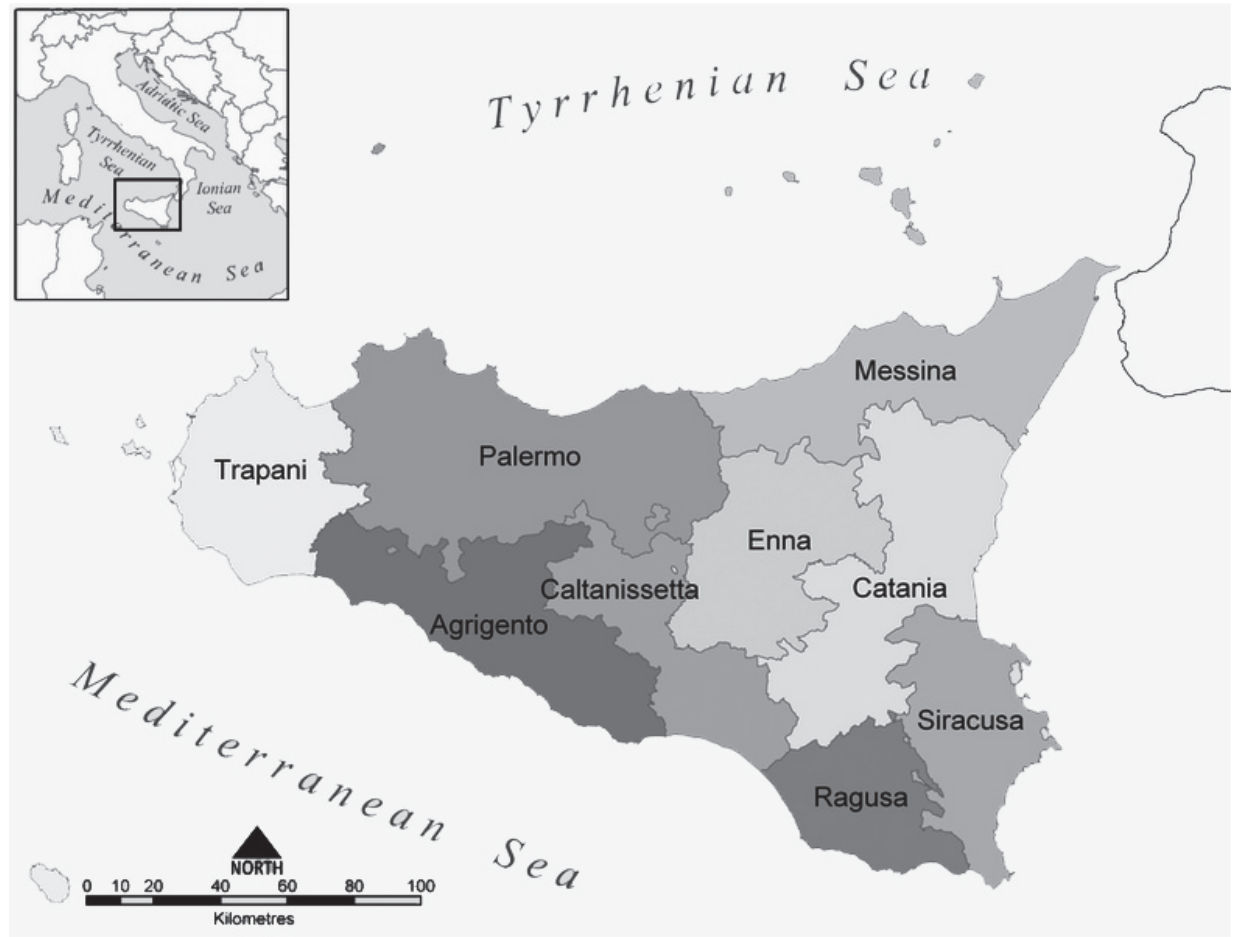

Italy, officially the Italian Republic, is subdivided into 20 regions, of which five, including Sicily, are constitutionally given a broad amount of autonomy granted by special statutes that enable them to enact legislation on some of their local matters. ${ }^{8}$ The nation is further divided into 110 provinces and 8,101 communes (municipalities). ${ }^{9}$ A recent law aiming at abolishing provinces and creating

8 For statistical purposes, the Italian regions are grouped as follows:

Northwest: Valle d'Aosta, Liguria, Lombardia, Piemonte;

Northeast: Emilia-Romagna, Friuli-Venezia Giulia, Trentino - Alto Adige, Veneto;

Centre: Lazio, Marche, Toscana, Umbria;

South: Abruzzo, Puglia, Basilicata, Molise, Campania, Calabria, Sicilia, Sardegna.

9 Throughout this paper, we will refer to regions and provinces by their Italian institutional names, although there are English-languages equivalents for some of these identities. We could have opted to use Tuscany for Toscana, or Sardinia for Sardegna, or, again, Aosta Valley for Valle d'Aosta and Apulia for Puglia. We could also have chosen Syracuse for Siracusa. We believe that the consistent adoption of the official Italian designations will add a touch of Italian flavour to our analysis. The only exception for this is the Sicilian region, for which the term Sicily and Sicilia are used interchangeably. 
associations of communes is not yet operational. Sicily is the largest Italian region: with a surface of $25,832,38$ square kilometres, it represents 8.5 per cent of the whole national territory. It is the fourth most populated region in Italy: its population of more than 5 million residents is 8.4 per cent of the whole of Italy. Sicily is officially referred to as the Sicilian region. Its capital is Palermo. The region is administratively subdivided into nine provinces: Agrigento, Catania, Palermo, Messina, Siracusa, Trapani, Ragusa, Enna, and Caltanissetta, each with a main city of the same name as the province. Small surrounding islands are also part of some provinces: the Aeolian Islands (Messina); Isle of Ustica (Palermo); Isle of Pantelleria; Aegadian Islands (Trapani) and Pelagian Islands (Agrigento). The nine Sicilian provinces are highlighted in different shades in Figure 4. They all have borders on the sea, except for the province of Enna, which is entirely landlocked.

Both in terms of population and territorial surface, Palermo and Ragusa are respectively the largest and the smallest of the Sicilian provinces (Table 1). Located in the southeast of Sicily, the province of Ragusa is also characterized by having a main city which is the southernmost provincial capital in Italy.

Table 1. Surface area and population of the nine Sicilian provinces, 2013

\begin{tabular}{|l|r|r|r|r|}
\hline Provinces & \multicolumn{2}{l|}{ Surface } & \multicolumn{2}{l}{ Population } \\
\hline & $\mathrm{km}^{2}$ & $\%$ & value & $\%$ \\
\hline Agrigento & $3,052.59$ & 11.82 & 448,831 & 8.81 \\
\hline Caltanissetta & $2,138.37$ & 8.28 & 274,731 & 5.39 \\
\hline Catania & $3,573.68$ & 13.83 & $1,115,704$ & 21.90 \\
\hline Enna & $2,574.70$ & 9.97 & 172,456 & 3.38 \\
\hline Messina & $3,266.12$ & 12.64 & 648,371 & 12.73 \\
\hline Palermo & $5,009.28$ & 19.39 & $1,275,598$ & 25.04 \\
\hline Ragusa & $1,623.89$ & 6.29 & 318,249 & 6.25 \\
\hline Siracusa & $2,124.13$ & 8.22 & 404,847 & 7.95 \\
\hline Trapani & $2,469.62$ & 9.56 & 436,150 & 8.56 \\
\hline Sicily & $25,832.38$ & 100.00 & $5,094,937$ & 100.00 \\
\hline
\end{tabular}

Source: Istituto centrale di statistica, 2014a 
The most comprehensive framework law regulating tourism in Italy is Law no. 135 of 29 March 2001, Reform of the National Law on Tourism, strongly innovative in its form and in its substance and content with respect to previous legislation. On the whole, while defining the basic principles and tools of tourism policy, the Law entrusts the Italian Republic with the task of turning the tourist sector into a strategic factor for the social development of the nation; for the overcoming of regional disparities; for the protection and safeguarding of environmental and cultural resources. Furthermore, it regulates the "regional character of tourism". Following constitutional amendments, with Law no. 181 of 18 May 2006, the overall responsibility at national level was conferred on the Prime Minister's Office, where the Department of Tourism was set up through Law no. 286 of 24 November 2006. At the regional and local level, the Constitution itself (Art. 117) entitles regions and autonomous provinces to exercise exclusive legislative powers. Therefore, each one of the 20 Italian regions has its own laws and regulations in the field of tourism. According to the basic principle of subsidiarity, the region is thus the most appropriate institution to legislate on the tourist sector, while central government maintains only certain limited competencies.

Sicily moved in the same direction as national legislation with regional Law no. 10 of 15 September 2005, containing 'Rules for tourism development in Sicily and urgent financial provisions'. Article 1 of this Law, amongst other things, attributes "a primary and central role to tourism" in order to ensure the sustainable development of the territory, "taking account of the widespread tourism potential of Sicily". The actual introduction of tourism sustainability at regional level was contingent on the formulation of a three-year plan for regional tourism development, which establishes "the global objectives and priorities of the administrative activity, identifying the incentive system for infrastructures and works of tourism exploitation of the territory, outlines the promotional and marketing plan for tourism supply, of the events and manifestations of tourism appeal, identifies the projects elaborated by tourist districts and determines the criteria for verifying the outcomes of planning activity" (Art. 3). In implementing this legislative provision, the Regional Tourism Department elaborated the 2007-2009 three-year plan, which was then submitted to the relevant regional authority office for necessary approval and to satisfy the further administrative requirements in the matter. But failure to establish the regional Tourism Council, the creation of which was required under Law no. 10, and the subsequent impossibility to obtain its mandatory opinion in the field of tourism development, blocked the administrative process of the plan's approval. Nevertheless, the draft plan was transmitted to tourist operators 
and stakeholders ${ }^{10}$, since in any case it represented the first planning document aimed at analyzing objectives and implementing strategies and tools in order to ensure tourism sustainability in the presence of strong financial constraints.

The premise of the three-year plan had a twofold objective: to compare the Sicilian hospitality industry with the industry at national level and to analyze the role played by single regional provinces in Sicilian tourism. This second objective was based on the elaboration of some indicators aimed at estimating the impact that the Sicilian demand and supply of hospitality produces on the regional territory in terms of the three basic pillars of sustainable development, namely economic, environmental and social sustainability. ${ }^{11}$ In order to have a better comprehension of the varied aspects of tourism sustainability in Sicily, we make reference to a grid of indicators wider than that contained in the three-year plan.

This battery of indicators is reported in Table 2, where $P L$ is the number of bed places available in the tourism industry in the selected province (hotels and similar accommodation and other collective accommodation establishments); $S$ is the territorial dimension of the province (in square kilometres); $P$ is the population of the province; $A R$ and $P R$ are respectively the arrivals and the presences (by residents and non-residents) recorded in the particular area; $E$ is the number of hotel establishments in the province; $G$ is the number of days (360) to be considered in the analysis; $R$ is the number of rooms in the hotel industry of the province; $B$ is the number of bathrooms in the hotel industry of the province; $c$ is the hotel category according to a five-star system; $L$ is the number of bed places available in each province for any hotel quality category; $c w$ is the regional total of the particular hotel quality; and $i$ the province of reference.

10 Stakeholders in tourism include a wide range of participants who have both rights and responsibilities within the sector. From a general perspective, six main stakeholder groups have been identified as having interests in the development process towards sustainable tourism (Swarbrooke, 1999): the public sector, the tourism industry, voluntary sector organizations, the host community, the media, and the tourist. Because there is a need for partnership and cooperation between the various stakeholders in tourism sustainable development, however, it must be recognized that stakeholder groups may have divergent goals and aims in the allocation process, through which the overall socio-economic effects can be maximized. This consideration can result in competition for limited financial resources, questions of equity and distribution, and the exigency to find a sound balance between the costs and benefits of various political decisions (Milne, 1998).

11 This estimate of the indicators addressing the economic, environmental and social impacts of tourism follows what was contained in the Report on Sicilian Tourism elaborated with reference to 2005 by the Sicilian Tourism Observatory, taking into consideration the commune, either individually or grouped together (Osservatorio turistico della Regione siciliana, 2005). 
Table 2. Tourism indicators for the nine Sicilian provinces

\begin{tabular}{|l|l|}
\hline Indicators & Denomination \\
\hline $\mathrm{Di}=(\mathrm{PL} / \mathrm{S})$ & Index of territorial density of tourism \\
\hline $\mathrm{Fi}=(\mathrm{PL} / \mathrm{P}) \cdot 1000$ & Index of tourist function \\
\hline $\mathrm{Ci}=(\mathrm{P} / \mathrm{PR}) \cdot 100$ & Index of touristship \\
\hline $\mathrm{Ui}=(\mathrm{AR}+\mathrm{P}) / \mathrm{S}$ & Index of territorial employment \\
\hline $\mathrm{Vi}=[\mathrm{PR} /(\mathrm{PL} \cdot \mathrm{Gt})] \cdot 1000$ & Index of occupancy of tourist establishments \\
\hline $\mathrm{Ei}=(\mathrm{R} / \mathrm{E})$ & Index of economic efficiency of hotel industry \\
\hline $\mathrm{Mi}=(\mathrm{PR} / \mathrm{AR})$ & Index of territorial attraction \\
\hline $\mathrm{Ni}=(\mathrm{B} / \mathrm{R}) \cdot 100$ & Index of comfort of hotel establishments \\
\hline $\mathrm{Qi}=\sum \mathrm{C}(\mathrm{Lci} / \mathrm{Lcw}) \cdot 100$ & Index of hotel quality \\
\hline
\end{tabular}

The $D$ indicator, supplying the bed places per square kilometre, tries to estimate the impact of tourist supply on the territory: greater values of $D$ indicate a greater territorial impact of tourism accommodation infrastructures. ${ }^{12}$ The $F$ indicator, measuring the impact of tourism hospitality on the socio-economic situation of the territory (Defert, 1966; 1967), provides information on the capacity of a territory to absorb tourism activity from a demographic perspective: the higher $F$ is, the more the tourism accommodation infrastructure influences the local economy. ${ }^{13}$ The $C$ indicator measures the existing relation between the tourist

12 The index $D$ is usually classified as follows:

\begin{tabular}{|c|c|}
\hline Size thresholds & Impact of tourist supply on the physical territory \\
\hline $0 \leq \mathrm{D} \leq 8.80$ & no or negligible \\
\hline $8.80<\mathrm{D} \leq 25$ & medium-high \\
\hline $25<\mathrm{D} \leq 50$ & high \\
\hline $50<\mathrm{D} \leq 100$ & very high \\
\hline $\mathrm{D}>100$ & extremely heavy to be monitored carefully \\
\hline
\end{tabular}

13 According to Boyer (1972), the index $F$ is classified as follows:

\begin{tabular}{|c|c|}
\hline Size thresholds & $\begin{array}{l}\text { Impact of tourist supply on the socio-economic situation } \\
\text { of the territory }\end{array}$ \\
\hline $0 \leq \mathrm{F} \leq 75.21$ & $\begin{array}{l}\text { provinces with few tourist activities that are not able to influence meaning- } \\
\text { fully tourism development }\end{array}$ \\
\hline $75.21<\mathrm{F} \leq 100$ & provinces where tourism is a significant but non-dominant sector \\
\hline $100<\mathrm{F} \leq 500$ & provinces where tourism is very important, but alongside other sectors \\
\hline $500<\mathrm{F} \leq 1000$ & $\begin{array}{l}\text { provinces where tourism dominates the local economy, while very little } \\
\text { space is reserved for other sectors }\end{array}$ \\
\hline $\mathrm{F}>1000$ & provinces saturated economically by the tourist sector \\
\hline
\end{tabular}


and the local community in the area: the lower $C$ is, the greater the friction and conflict between these two entities. The $U$ indicator tries to assess the degree of use of the physical territory by man (indigenous and tourist): the higher $U$ is, the greater the degree of whole territorial exploitation occurs. The indicator $V$ makes a comparison between the nights effectively spent in all accommodation establishments and those potentially possible in order to measure the level of occupancy of tourist establishments: the higher $V$ is, the greater is the level of the supply that has been utilized. The $E$ indicator tries to appraise the economic efficiency of the tourist supply: once assumed that the widest dimension of the hotel industry (that is, the largest number of rooms in each establishment) ensures the best combination of productive inputs within it, thus: the higher $E$ is, the greater economic efficiency is reached by accommodation establishments. The $M$ indicator tries to estimate the attraction that the territory exerts on the night spent in the hotel: the higher the average length of stay, the greater is the capacity of the territory to capture the tourist's interest to stop in the place. The $N$ indicator tries to appraise the comfort of hotel establishments: the greater the index, the more comfortable is the tourist experience and hence the higher customer satisfaction is. The $Q$ index is based on the hotel classification involving stars, with a greater number of stars indicating greater luxury (Mirloup, 1974). This index varies from 0 to 1,500 , which represents the regional total: the higher $Q$ is, the greater is the quality of hotel supply in the province.

The basis for the elaboration of these indicators is supplied by data contained in the survey on the capacity and occupancy of tourist accommodation establishments that the National Institute of Statistics (ISTAT) has provided for the year 2013 according to EU Regulation 692/2011 concerning European statistics on tourism. In this survey, accommodation establishments are classified into two main types: (1) hotels and similar accommodation; and (2) other collective accommodation establishments.

The data reported in Table 3 and Table 4 show the main aspects of the Sicilian hospitality system in absolute and per cent terms, respectively. For the year 2013, Messina and Palermo are the provinces which play a major role in the tourism market. In terms of demand, they register the largest amount of arrivals and presences in all accommodation establishments; in terms of supply, they record the largest availability of each aspect of hotel hospitality, owning almost 50 per cent of establishments, rooms, beds places and bathrooms of the regional accommodation capacity. This twin result probably finds its justification in the existence within their territory of localities with long-established tourist appeal (Cefalù, Monreale, Bagheria, in Palermo province; Taormina, the Aeolian Islands and the area surrounding Capo d'Orlando-Tindari, in Messina province) 


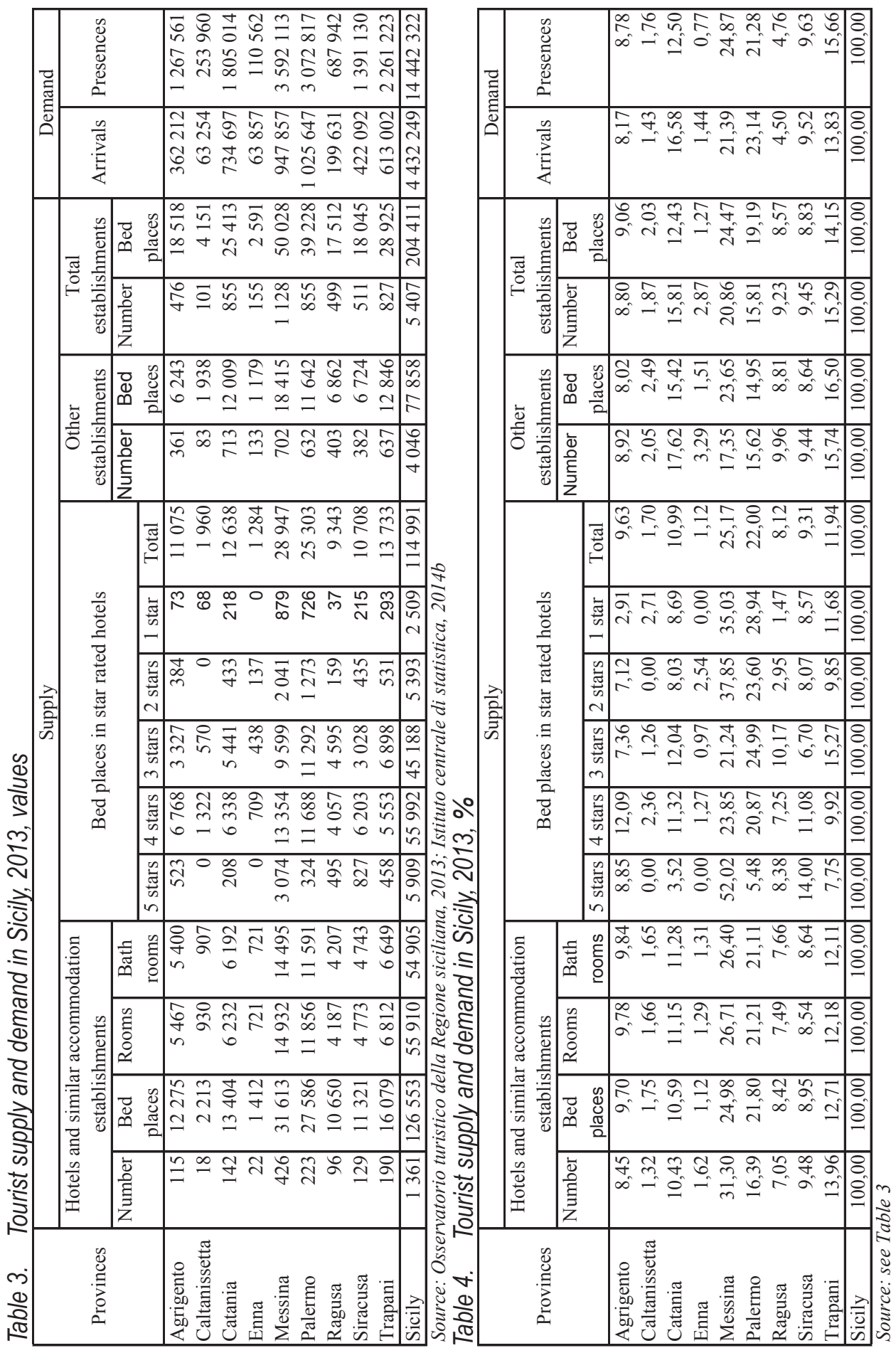


and the fact that the provinces are important link points between the rest of Italy and other Sicilian localities. At the same time, Caltanissetta and Enna are less attractive provinces because of their distance from the sea (partially in the case of Caltanissetta, and totally for landlocked Enna) and the lack of adequate access systems towards them.

Calculations made on capacity and occupancy of tourist accommodation establishments yield the indexes underlying tourism sustainability in the nine Sicilian provinces (see Table 5).

Table 5. Tourism indicators in the nine Sicilian provinces, 2013

\begin{tabular}{|l|r|r|r|r|r|c|c|r|}
\hline Provinces & \multicolumn{1}{c|}{$\mathrm{D}_{\mathrm{i}}$} & \multicolumn{1}{c|}{$\mathrm{F}_{\mathrm{i}}$} & \multicolumn{1}{c|}{$\mathrm{C}_{\mathrm{i}}$} & \multicolumn{1}{c|}{$\mathrm{U}_{\mathrm{i}}$} & $\mathrm{V}_{\mathrm{i}}$ & $\mathrm{E}_{\mathrm{i}}$ & $\mathrm{M}_{\mathrm{i}}$ & \multicolumn{1}{c|}{$\mathrm{N}_{\mathrm{i}}$} \\
\hline Agrigento & 6,07 & 41,26 & 35,41 & 265,69 & 19,01 & 47,54 & 3,50 & 98,77 \\
Caltanissetta & 1,94 & 15,11 & 108,18 & 158,06 & 16,99 & 51,67 & 4,01 & 97,53 \\
Catania & 7,11 & 22,78 & 61,81 & 517,79 & 19,73 & 43,89 & 2,46 & 99,36 \\
Enna & 1,01 & 15,02 & 155,98 & 91,78 & 11,85 & 32,77 & 1,73 & 100,00 \\
Messina & 15,32 & 77,16 & 18,05 & 488,72 & 19,95 & 35,05 & 3,79 & 97,07 \\
Palermo & 7,83 & 30,75 & 41,51 & 459,40 & 21,76 & 53,17 & 3,00 & 97,76 \\
Ragusa & 10,78 & 55,03 & 46,26 & 318,91 & 10,91 & 43,61 & 3,45 & 100,48 \\
Siracusa & 8,50 & 44,57 & 29,10 & 389,31 & 21,41 & 37,00 & 3,30 & 99,37 \\
Trapani & 11,71 & 66,32 & 19,29 & 424,82 & 21,72 & 35,85 & 3,69 & 97,61 \\
\hline Sicily & 7,91 & 40,12 & 35,28 & 368,81 & 19,63 & 41,08 & 3,26 & 98,20 \\
\hline
\end{tabular}

Source: see Table 3

The index of territorial density of tourism $(D)$ shows that the sector produces no or negligible impact on Sicilian territory. A value greater of the regional average (7.91) is reported by the provinces of Messina (15.32), Trapani (11.71) and Ragusa (10.78). The provinces of Enna (1.01) and Caltanissetta (1.94) record the lowest value for this index.

The index of tourist function $(F)$ highlights a region scarcely influenced by tourism activities and with strong differences between the different local situations. Its average value (40.12) is exceeded by the provinces of Messina (77.16), Trapani (66.32), Ragusa (55.03), Siracusa (44.57) and Agrigento (41.26), with the lowest values recorded for Caltanissetta (15.11) and Enna (15.02).

The index of touristship $(C)$ shows low contrasts between tourists and residents in the inland Sicilian provinces, Caltanissetta and Enna, which respectively 
record 108.18 and 155.98 for this indicator. The index value is lowered (and therefore the friction increases) in coastal areas, reaching its minimum value (maximum conflict) in the provinces of Messina (18.05) and Trapani (19.29).

The index of territorial employment $(U)$, with an average value of 368.81 , shows that the provinces with the greatest impact on the territory by man (both tourists and residents) are Catania (517.79), Messina (488.72), Palermo (459.40), Trapani (424.82) and Siracusa (389.31), namely those provinces that show an index value greater than the regional average. In the last places of the ranking we once again find the provinces of Caltanissetta and Enna, whose indicator values record a difference of 210.75 and 277.03 points respectively compared to the regional average.

According to the index of occupancy of tourist establishments $(V)$, the province of Palermo records the maximum tourist flow; the provinces of Trapani and Siracusa follow close, with the three provinces presenting an index value greater than 20. The provinces of Caltanissetta and Enna record the lowest values for this indicator.

The index $E$ shows that the greater economic efficiency in the performance of tourism activity is recorded by the province of Caltanissetta (51.67). On the other hand, the province of Enna (32.77) once again records the lowest indicator value.

The index $M$ shows that the greater territorial attraction of tourist resources is still recorded by the province of Caltanissetta in which the average length of stay (4.01 nights spent per visit) exceeds the average regional value by 0.75 points (three-quarters of one day longer).

The index $N$ shows that the level of comfort in Sicilian hotel establishments is very high, with a value close to 100 per cent for all provinces. Furthermore, six of the nine provinces record an indicator value higher than the regional average (98.20).

According to the index $Q$, after remembering that its higher values are reported by provinces with hotels of higher quality expressed in stars and that its regional total is 1,500 , we find that the province of Messina records the best result. In fact, for this province the index (529.95) is more than one third of the regional total. The province of Palermo ranks second, recording an indicator value that is almost half of that expressed by the leading province.

The indicators reported in Table 4 show that in the year 2013 some provinces performed better than others with respect to the regional average. In this sense, it 
is important to recognize the preeminent role played by the province of Messina, while the provinces of Caltanissetta and Enna performed worse. However, the negative evaluation regarding Caltanissetta has to be interpreted taking into account that the province recorded the best result for two of the selected indicators. The consideration of the position of each province with respect to the regional average for each indicator of the grid outlines a picture difficult to interpret in a meaningful manner. A more satisfying solution is instead to normalize each indicator measure on the basis of the best or worst value in the particular ranking (Giacalone, La Tona \& Marino, 2005). This procedure starts by giving a score for all the nine indicators, coming from the attribution of 100 points to the province with the best outcome and a proportionally lower value to all the others according to the following formula:

$$
T\left(x_{i}\right)=100 \frac{\min \left\{x_{i}\right\}}{x_{i}}
$$

or

$$
T\left(x_{i}\right)=100 \frac{x_{i}}{\max \left\{x_{i}\right\}}
$$

where $x_{i}$ is the value registered by each province and $T\left(x_{i}\right)$ is the value transformed with (1) or (2), depending on whether the better outcome, in function of the specific content of the index, is respectively the lower or the higher value. The 9 rankings are thus made. At the end, we can apply the following formula (3):

$Z_{i}=\frac{1}{9} \sum_{i=1}^{9} T\left(x_{i}\right)$

in order to obtain a final ranking in which the position of each province is estimated from the average between the score obtained in each of the 9 indicators. Using the $Z_{i}$ indicator, the contribution of each Sicilian province to tourism sustainability is shown by the last column of Table 6 , which reassumes the typical peculiarities of sustainability itself.

Once again, Table 6 shows that the province of Messina has performed better with respect to tourism sustainability in Sicily, expressing both a wide openness to the hospital industry (hotels and similar accommodation and other collective accommodation establishments) and relevant use of tourist resources that avoids their irreversible depletion. The weak link in the difficult path towards sustainable tourism development is represented by the inland provinces of Caltanissetta and Enna. A different view of how the Sicilian provinces move towards tourism sustainability is shown in Table 7, which expresses the $Z_{i}$ index for size thresholds. 
Table 6. $\quad Z_{i}$ indicator for the nine Sicilian provinces, 2013

\begin{tabular}{|c|c|c|c|c|c|c|c|c|c|c|c|c|c|}
\hline \multirow[t]{2}{*}{ Provin-ces } & \multirow{2}{*}{$\begin{array}{c}D_{i} \\
\text { score }\end{array}$} & \multirow{2}{*}{$\begin{array}{c}\mathrm{F}_{\mathrm{i}} \\
\text { score }\end{array}$} & \multirow{2}{*}{$\begin{array}{c}\mathrm{C}_{\mathrm{i}} \\
\text { score }\end{array}$} & \multirow{2}{*}{$\begin{array}{c}\mathrm{U}_{\mathrm{i}} \\
\text { score }\end{array}$} & \multirow{2}{*}{$\begin{array}{c}V_{i} \\
\text { score }\end{array}$} & \multirow[t]{2}{*}{$E_{i}$} & \multirow[t]{2}{*}{$M_{i}$} & \multirow[t]{2}{*}{$\mathrm{N}_{\mathrm{i}}$} & \multirow[t]{2}{*}{$Q_{i}$} & \multicolumn{2}{|c|}{ Score } & \multirow{2}{*}{$\begin{array}{c}\mathrm{Z}_{\mathrm{i}} \\
\text { index }\end{array}$} & \multirow{2}{*}{$\begin{array}{c}\text { Ranki } \\
\text { ng }\end{array}$} \\
\hline & & & & & & & & & & Total & Average & & \\
\hline grigento & 39,60 & 53,47 & 22,70 & 51,31 & 87,38 & 92,01 & 87,16 & 98,30 & 24,88 & 556,83 & $\begin{array}{lll}311,37 \\
\end{array}$ & 73,61 & 7 \\
\hline $\begin{array}{l}\text { Caltanis- } \\
\text { setta }\end{array}$ & 12,67 & 19,58 & 69,35 & 30,53 & 78,10 & 100,00 & 100,00 & 97,06 & 3,01 & 510,31 & 102,06 & 67,46 & 8 \\
\hline Catania & 46,43 & 29,52 & 39,63 & 100,00 & \begin{tabular}{|c|}
90,67 \\
\end{tabular} & 84,94 & 61,19 & 98,89 & 23,35 & 574,62 & 114,92 & $\begin{array}{l}75,96 \\
\end{array}$ & 5 \\
\hline Enna & 6,57 & 19,47 & 100,00 & \begin{tabular}{|l|}
17,73 \\
\end{tabular} & 54,48 & 63,43 & 43,12 & 99,52 & 2,46 & 406,78 & \begin{tabular}{l|l}
381,36 \\
\end{tabular} & \begin{tabular}{|l|l|}
53,77 \\
\end{tabular} & 9 \\
\hline Messina & 100,00 & 100,00 & 11,57 & 94,39 & 91,66 & 67,84 & 94,39 & 96,61 & 100,00 & 756,47 & 151,29 & 100,00 & 1 \\
\hline Palermo & 51,13 & 39,86 & 26,61 & 88,72 & 100,00 & 102,90 & 74,62 & 97,30 & 49,44 & 630,59 & 126,12 & 83,36 & 3 \\
\hline Ragusa & 70,40 & $\begin{array}{l}71,31 \\
\end{array}$ & 29,66 & 61,59 & 50,15 & 84,42 & 85,83 & 100,00 & 20,52 & 573,89 & 114,78 & $\begin{array}{l}75,86 \\
\end{array}$ & 6 \\
\hline Siracusa & 55,46 & 57,77 & 18,66 & 75,19 & 98,42 & 71,61 & 82,09 & 98,90 & 30,02 & 588,11 & 117,62 & \begin{tabular}{ll|}
77,74 \\
\end{tabular} & 4 \\
\hline Trapani & 76,46 & 85,95 & 12,37 & 82,05 & 99,80 & 69,39 & 91,88 & 97,14 & 29,36 & 644,40 & 128,88 & 85,19 & 2 \\
\hline
\end{tabular}

Source: see Table 3

Table 7. $\quad Z_{i}$ index for size thresholds on provincial scale in Sicily

\begin{tabular}{|c|c|c|}
\hline Size thresholds & Impact on tourism sustainability & Provinces \\
\hline $0 \leq Z \leq 60$ & low & Enna \\
\hline $60<Z \leq 70$ & modest & Caltanissetta \\
\hline $70<Z \leq 80$ & satisfactory & Agrigento, Ragusa, Catania, Siracusa \\
\hline $80<Z \leq 90$ & good & Palermo, Trapani \\
\hline $90<Z \leq 100$ & high & Messina \\
\hline
\end{tabular}

According to this presentation, the ranking of the Sicilian provinces follows a five-part subdivision. At the bottom of the ranking lies the province of Enna. Next comes the province of Caltanissetta. These provinces share a common aspect as they refer to territories with large potential, as the tourism industry is still underdeveloped there, even though they possess the indispensable attractions for sustainable development. Continuing the ranking, we find the provinces of Agrigento, Ragusa, Catania and Siracusa, which effectively represent a rather homogeneous subset in terms of their satisfactory contribution to tourism sustainability. A further step ahead are the provinces of Palermo and Trapani, both located in western Sicily. The ranking concludes with the province of Messina, clearly far from the provinces placed in the second best positions.

If the provinces in the top positions are those in which the tourist industry is undoubtedly more developed, it is equally true that they can show over time a higher risk of deterioration of the environmental, economic and social aspects of tourism sustainability. As a result of this process, in the long run, an over-exploitation of tourist resources might occur. In this perspective, the 
important question is how to deliver sustainable development in the different localities taking into account that the dimensions of sustainability are in many ways interdependent and can be mutually reinforcing or in competition. Hence it is necessary to find a sound balance between them, so that the regional tourism sector, as a whole, can take full account of the opportunities offered by all forms of tourism in all types of destinations. Obviously, the search for and implementation of policies for sustainable tourism should be based on a number of overarching principles and approaches. Some of these are inherent to the general principles of tourism sustainability while others can be identified with reference to the specific features of Sicilian tourism. Amongst these latter policies are those aimed at diverting the tourist demand from areas where it is most significant to territories where the tourist flow is less intense, relying on the peculiar natural and cultural aspects of the Sicilian localities. Equally important could be policies aimed at obtaining seasonal adjustments of incoming tourists, since the wide presence of guests in certain periods of the year makes ecosystems particularly vulnerable. Moreover, distributing tourist demand more consistently and evenly over time would ensure that local economies strongly dependent on tourism development receive a more regular income flow and therefore garner a constant benefit for indigenous communities.

These normative recommendations should be carefully considered taking into account the main aspect of Sicilian tourism, historically based on the favorable weather conditions for about ten months a year and the attractiveness of the coastline and the smaller islands off the main island. As highlighted by experience, seasonality can be largely considered as a physiological characteristic of Sicilian tourism that involves the heavy concentration of tourist flows in relatively short periods of the year in a specific destination. ${ }^{14}$ Because

14 Although there is no a widely accepted notion of seasonality in tourism, there have been numerous attempts to define the concept in the tourism industry (Cavallo \& Santoro, 2014). As a pioneer in seasonality, BarOn (1973, p. 53) stated: "[Seasonality] implies an incomplete and unbalanced utilization of the means at the disposal of the economy, and this is similar to the imbalance of the business cycle, where the economy is either overheated or running under full potential at different phases of the cycle". Furthermore, BarOn (1975) defined seasonality as the effects occurring every year due to climate status, constraints of public holidays, special attractions, or personal lifestyle. On the basis of BarOn's research, Butler (1994) affirmed that seasonality is associated with temporal imbalance in the phenomenon of tourism, which may be expressed in terms of different dimensions including numbers and expenditures of visitors, transportation traffic and employment. Quite similar definitions of seasonality in tourism were provided by Wall and Mathieson (2006) and Cooper et al. (2008). In order to understand the main aspect of tourism seasonality, see Chung (2009), O'Mahony and McMurray (2008), Baum and Lundtorp (2011), Cannas (2012), and Petreska (2013). 
of this feature, Sicily has a tourist demand with a peak in August and one of lesser intensity in springtime, near the Easter holidays. Similarly, the average lengths of stay increase with summertime, when the bathing season reaches its peak. In this period this indicator increases by more than 1 day compared to the annual average, assuming in August a value of almost 4.5 days per visit, before recording values slightly longer than 2 days in the low seasons.

Obviously, all normative prescriptions that could be suggested in terms of tourism policy may benefit from a better calculation of the $Z_{i}$ index, as the indicator provides helpful information on the areas most affected by the tourist industry and their specific environmental, social and economic dimensions of tourism sustainability. The greater the knowledge of the three components of sustainability, the greater is the capacity of strategies, actions and tools to make sustainable tourism development more homogeneous between the different Sicilian localities and territories. Surely, to enhance the significance of this indicator, its estimate should be founded on a battery of indexes wider than those utilized in this paper. The adoption of appropriate weightings of the environmental, economic and social dimension of tourism sustainability will be important as well. It would reflect the relative preference assigned by public decision-makers to each pillar of sustainability, thus making the political sphere's view of the compromise between the three pillars all the more tangible.

In this direction, many insights would come from the approval of the three-year plan for Tourism Development providing the guidelines underlying the political decisions to be made. However, to date no three-year plan has been approved. ${ }^{15}$ Nevertheless, the importance of this planning document has been well recognized.

15 In this direction, it will be helpful if the three-year plan refers to the Strategic Plan for the Development of Tourism in Italy, recently formulated by the Italian Government (Presidenza del Consiglio dei Ministri, 2013). This strategic plan, after expressing the weakness and the potential of the Italian tourism sector, identifies actions, goals and tools that have to be undertaken to ensure tourism sustainability at any level within the concept of shared responsibility requiring a much more broadly-based and active involvement of all economic players including public authorities, public and private enterprise in all its forms, and, above all, the general public both as citizens and consumers.

Effectively, community participation has long been viewed as an important tenet of tourism planning, and there is consensus among researchers that engaging all stakeholder groups contributes to tourism sustainability. However, there are gaps in the literature, and challenges in practice, that call for further research, mainly in the direction to find adequate tools to make effective the participation of all stakeholders in all stages of the decision-making process underlying tourism sustainability. On this issue, see Byrd (2007), Waligo, Clarke and Hawkins (2013), and Özçevik, Brebbia and Şener (2015). 
Finally, the central role assigned to the three-year plan was outlined by a Presidential Directive of 2014 that bases the achievement of regional tourism sustainability on the systematic application of the planning procedure within the process of resource allocation. If this expression of political commitment is translated into effective policies and strategies, then it will be possible to view tourism sustainability as the result of the amalgam of three important elements: a set of clearly defined objectives; a system of tourism indicators aimed at evaluating the fulfillment of the established goals; a list of actions selected in the light of their capacity to influence the territorial context of reference. In this perspective, the three-year plan for tourism development would represent "first of all a compass, of which objectives and measurement system are needle and magnet" (Osservatorio turistico della Regione siciliana, 2014, p. 7).

\section{Tourism sustainability at regional level in Italy}

In a wider perspective, the approach used to make a comparison of tourism sustainability at provincial scale can be applied to analyze sustainable tourism development in the different Italian regions. In this direction, Tables 8 and 9 show the essential elements of the supply and the demand of tourism industry at regional level. For the year 2013, as regards hotels and similar accommodation establishments, Trentino-Alto Adige, Veneto and Emilia-Romagna, all in Northern Italy, record the best results for all aspects of the supply. On the whole, in terms of large territorial areas, the North records $60.13 \%, 51.73 \%, 54.24 \%$ and $54.56 \%$ of the national consistency for the number of establishments, bed places, rooms and bathrooms, respectively. The South and the Centre follow in the ranking. As regards the other establishments in the total supply, the North again holds the first place in the ranking for both aspects mentioned in the Figure; the Centre and the South follow at a considerable distance. In terms of demand, Lombardia, another Northern region, records the best results $(22.51 \%$ and $22.72 \%$ of the arrivals and presences, respectively). Furthermore, the North shows more than $56 \%$ for both the aspects of the demand. As regards the arrivals and the presences, the second place in the ranking is occupied by the South, whilst the Centre lies at the bottom.

The demand and the supply of the hospitality industry offer the basis for the battery of the elementary tourism indicators of the twenty Italian regions. The indicators reported in Table 10 show that in the year 2013 some regions performed better than others with reference to the national average. For four of 


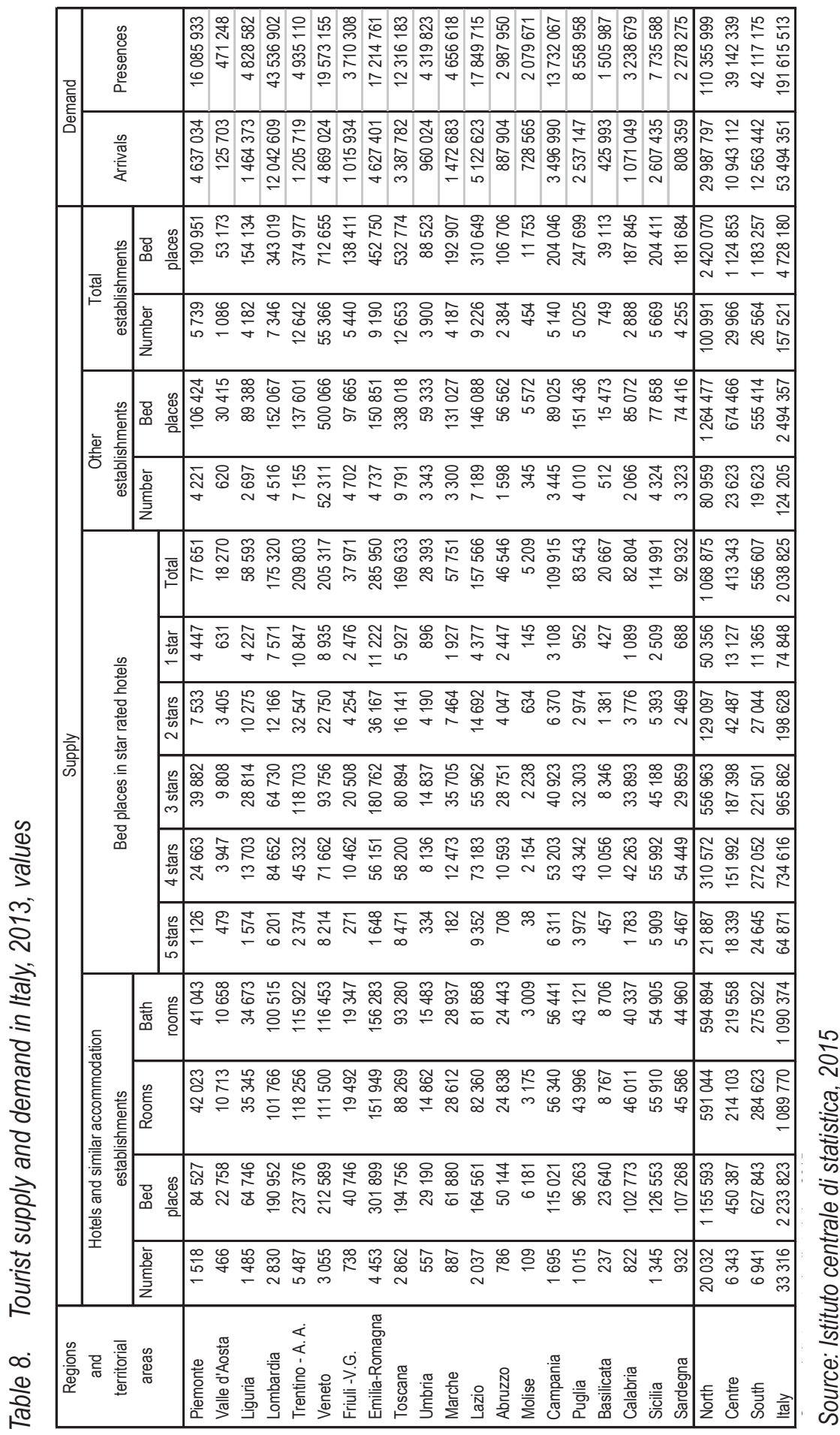




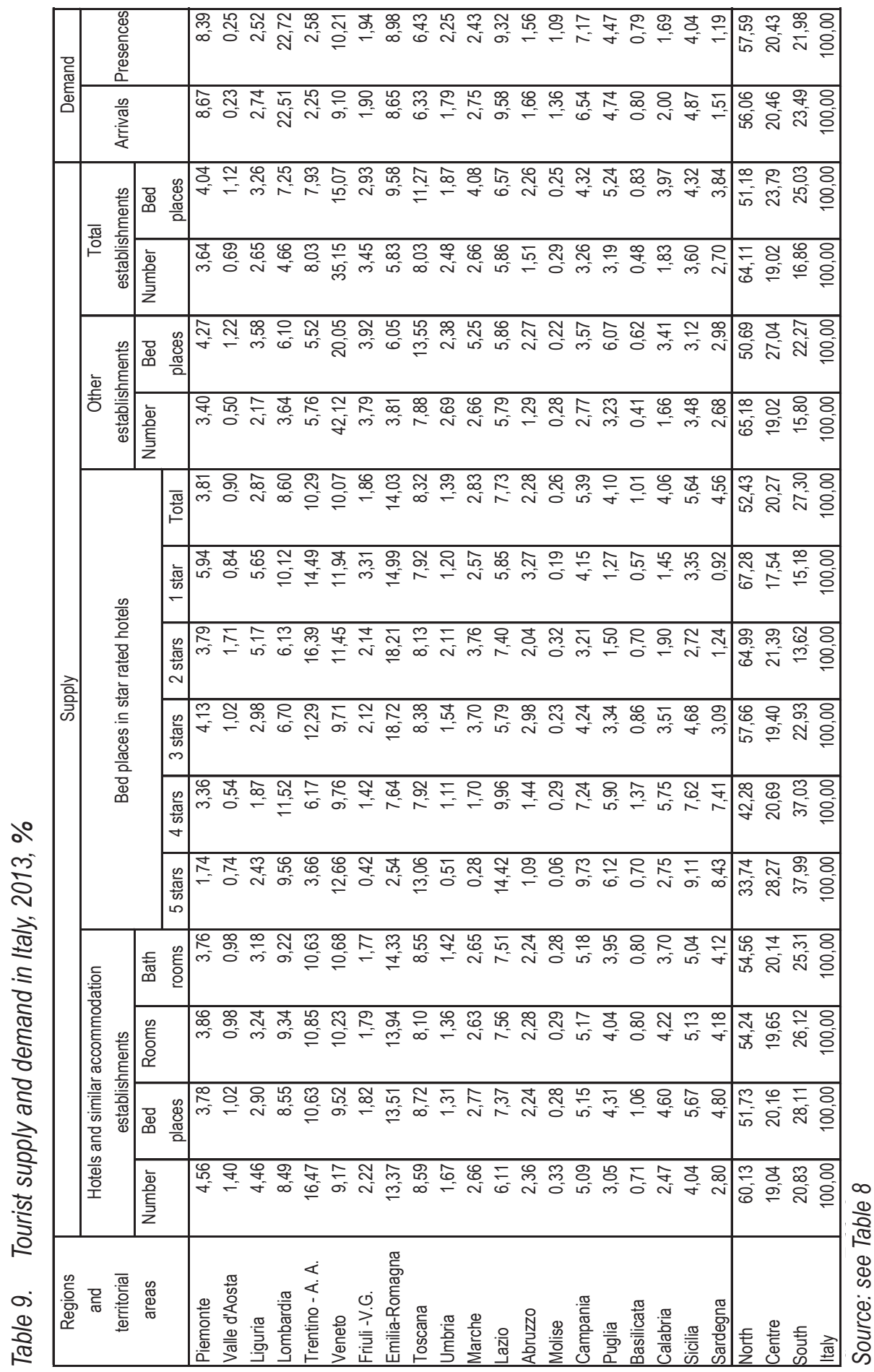


the nine indicators, the best results were recorded by Northern regions: Veneto $\left(D_{i}\right)$, Valle d'Aosta $\left(F_{i}\right)$, Lombardia $\left(U_{i}\right)$, and Veneto $\left(Q_{i}\right)$. For three indicators, the best outcomes were registered by Southern regions: Sardegna $\left(C_{i}\right)$, Molise $\left(V_{i}\right)$ and Calabria $\left(E_{i}\right)$, whilst two Central regions recorded the best results for two indicators: Umbria $\left(M_{i}\right)$ and Toscana $\left(N_{i}\right)$.

Table 10. Tourism indicators for the Italian regions, 2013

\begin{tabular}{|l|r|r|r|r|r|r|r|r|r|}
\multicolumn{1}{|c|}{$\begin{array}{c}\text { Regions } \\
\text { and }\end{array}$} & \multicolumn{1}{c|}{$\mathrm{Di}$} & \multicolumn{1}{c|}{$\mathrm{Fi}$} & $\mathrm{Ci}$ & $\mathrm{Ui}$ & $\mathrm{Vi}$ & $\mathrm{Ei}$ & $\mathrm{Mi}$ & $\mathrm{Ni}$ & $\mathrm{Qi}$ \\
\hline Piemonte & & & & & & & & & \\
Valle d'Aosta & 162,17 & 43,04 & 27,58 & 3572,03 & 23,40 & 27,68 & 3,47 & 97,67 & 48,02 \\
Liguria & 284,30 & 96,82 & 32,97 & 5637,34 & 8,70 & 23,80 & 3,30 & 98,10 & 44,54 \\
Lombardia & 143,75 & 34,39 & 22,91 & 9226,08 & 35,26 & 35,96 & 3,62 & 98,77 & 136,36 \\
Trentino - A. A. & 275,58 & 356,46 & 21,32 & 1659,22 & 3,66 & 21,55 & 4,09 & 98,03 & 127,11 \\
Veneto & 387,34 & 144,65 & 25,17 & 5324,16 & 7,63 & 36,50 & 4,02 & 104,44 & 166,30 \\
Friuli-V.G. & 176,13 & 112,59 & 33,13 & 2857,20 & 7,45 & 26,41 & 3,65 & 99,26 & 21,75 \\
Emilia-Romagna & 201,71 & 101,83 & 25,83 & 4042,56 & 10,56 & 34,12 & 3,72 & 102,85 & 150,83 \\
Toscana & 231,71 & 142,05 & 30,45 & 3104,48 & 6,42 & 30,84 & 3,64 & 105,68 & 146,28 \\
Umbria & 104,69 & 98,72 & 20,76 & 2195,79 & 13,56 & 26,68 & 4,50 & 104,18 & 17,03 \\
Marche & 205,97 & 124,20 & 33,35 & 3230,69 & 6,71 & 32,26 & 3,16 & 101,14 & 29,37 \\
Lazio & 180,23 & 52,92 & 32,89 & 6377,98 & 15,96 & 40,43 & 3,48 & 99,39 & 149,95 \\
Abruzzo & 99,14 & 79,99 & 44,64 & 2064,39 & 7,78 & 31,60 & 3,37 & 98,41 & 27,50 \\
Molise & 26,48 & 37,34 & 15,13 & 2350,98 & 49,15 & 29,13 & 2,85 & 94,77 & 2,99 \\
Campania & 150,14 & 34,76 & 42,75 & 6892,41 & 18,69 & 33,24 & 3,93 & 100,18 & 100,89 \\
Puglia & 127,96 & 60,56 & 47,79 & 3423,62 & 9,60 & 43,35 & 3,37 & 98,01 & 68,51 \\
Basilicata & 39,13 & 67,62 & 38,41 & 1004,93 & 10,70 & 36,99 & 3,54 & 99,30 & 13,55 \\
Calabria & 124,56 & 94,85 & 61,15 & 2023,52 & 4,79 & 55,97 & 3,02 & 87,67 & 52,54 \\
Sicilia & 79,50 & 40,12 & 65,86 & 2995,70 & 10,51 & 41,57 & 2,97 & 98,20 & 98,85 \\
Sardegna & 75,42 & 109,19 & 73,03 & 1026,25 & 3,48 & 48,91 & 2,82 & 98,63 & 84,46 \\
\hline North & 201,24 & 87,10 & 25,18 & 4804,02 & 12,67 & 29,50 & 3,68 & 100,65 & 708,06 \\
Centre & 193,77 & 93,19 & 30,84 & 3964,41 & 9,67 & 33,75 & 3,58 & 102,55 & 342,63 \\
South & 96,18 & 56,54 & 49,69 & 2722,22 & 9,89 & 41,01 & 3,35 & 96,94 & 449,30 \\
Italy & 156,91 & 77,79 & 31,72 & 3792,35 & 11,26 & 32,71 & 3,58 & 100,06 & 1500,00 \\
\hline
\end{tabular}

Source: see Table 8

The subsequent procedure of normalization of each indicator measure on the basis of the best or worst value in the particular ranking yields the estimate of the $Z_{i}$ indicators that shows the contribution of each Italian region to tourism sustainability. The last column of Table 11 expresses this result. 
Table 11. $Z_{i}$ indicator for the Italian regions, 2013

\begin{tabular}{|c|c|c|c|c|c|c|c|c|c|c|c|}
\hline \multirow[t]{2}{*}{ Regions } & \multirow{2}{*}{$\begin{array}{c}D_{i} \\
\text { score }\end{array}$} & \multirow{2}{*}{$\begin{array}{c}F_{i} \\
\text { score }\end{array}$} & \multirow{2}{*}{$\begin{array}{c}C_{i} \\
\text { score }\end{array}$} & \multirow{2}{*}{$\begin{array}{c}\mathrm{U}_{\mathrm{i}} \\
\text { score }\end{array}$} & \multirow{2}{*}{$\begin{array}{c}\mathrm{V}_{\mathrm{i}} \\
\text { score }\end{array}$} & \multirow{2}{*}{$\begin{array}{c}E_{i} \\
\text { score }\end{array}$} & \multirow{2}{*}{$\begin{array}{c}\mathrm{M}_{\mathrm{i}} \\
\text { score }\end{array}$} & \multirow{2}{*}{$\begin{array}{c}\mathrm{N}_{\mathrm{i}} \\
\text { score }\end{array}$} & \multirow{2}{*}{$\begin{array}{c}Q_{i} \\
\text { score }\end{array}$} & \multicolumn{2}{|c|}{ Score } \\
\hline & & & & & & & & & & Total & Averag \\
\hline Piemonte & 19,41 & 10,41 & 37,77 & 38,72 & 47,61 & 49,46 & 77,09 & 92,42 & 28,88 & 401,76 & 44,64 \\
\hline Valle d'Aosta & 42,07 & 100,00 & 37,36 & 8,45 & 5,01 & 41,07 & 83,31 & 94,14 & 7,91 & 419,33 & 46,5 \\
\hline -iguria & 73,40 & 23,41 & 45,14 & 61,10 & 17,70 & 42,52 & 73,28 & 92,83 & 26,78 & 456,17 & 50,6 \\
\hline Lombardia & 37,11 & 8,32 & 31,37 & 100,00 & 71,73 & 64,24 & 80,34 & 93,46 & 82,00 & 568,57 & 63,1 \\
\hline Trentino - A. A. & 71,15 & 86,20 & 29,19 & 17,98 & 7,44 & 38,50 & 90,96 & 92,76 & 76,44 & 510,63 & 56,7 \\
\hline Veneto & 100,00 & 34,98 & 34,47 & 57,71 & 15,52 & 65,20 & 89,34 & 98,83 & 100,00 & 596,05 & 66,2 \\
\hline Friuli -V.G. & 45,47 & 27,23 & 45,37 & 30,97 & 15,15 & 47,19 & 81,16 & 93,92 & 13,08 & 399,54 & 44,3 \\
\hline Emilia-Rom & 52,08 & 24,62 & 35,37 & 43,82 & 21,49 & 60,96 & 82,68 & 97,33 & 90,70 & 509,04 & 56,5 \\
\hline Toscana & 59,82 & 34,35 & 41,70 & 33,65 & 13,06 & 55,10 & 80,79 & 100,00 & 87,96 & 506,44 & 56,2 \\
\hline Umbria & 27,03 & 23,87 & 28,42 & 23,80 & 27,58 & 47,67 & 100,00 & 98,58 & 10,24 & 387,19 & 43,0 \\
\hline Marche & 53,18 & 30,04 & 45,67 & 35,02 & 13,64 & 57,63 & 70,27 & 95,70 & 17,66 & 418,81 & 46,5 \\
\hline Lazio & 46,53 & 12,80 & 45,03 & 69,13 & 32,47 & 72,23 & 77,44 & 94,05 & 90,17 & 539,86 & 59,9 \\
\hline Abruzzo & 25,60 & 19,35 & 61,13 & 22,38 & 15,82 & 56,46 & 74,79 & 93,12 & 16,54 & 385,17 & 42,8 \\
\hline Molise & 6,84 & 9,03 & 20,72 & 25,48 & 100,00 & 52,04 & 63,44 & 89,68 & 1,80 & 369,03 & 41,0 \\
\hline Campania & 38,76 & 8,41 & 58,53 & 74,71 & 38,03 & 59,38 & 87,27 & 94,80 & 60,67 & 520,56 & 57,8 \\
\hline Puglia & 33,04 & 14,65 & 65,44 & 37,11 & 19,53 & 77,44 & 74,97 & 92,75 & 41,20 & 456,11 & 50,6 \\
\hline Basilicata & 10,10 & 16,35 & 52,59 & 10,89 & 21,76 & 66,09 & 78,57 & 93,97 & 8,15 & 358,47 & 39,8 \\
\hline Calabria & 32,16 & 22,94 & 83,73 & 21,93 & 9,74 & 100,00 & 67,20 & 82,96 & 31,59 & 452,26 & 50,2 \\
\hline Sicilia & 20,53 & 9,70 & 90,19 & 32,47 & 21,39 & 74,26 & 65,93 & 92,93 & 59,44 & 466,83 & 51,8 \\
\hline Sardegna & 19,47 & 26,41 & 100,00 & 11,12 & 7,09 & 87,38 & 62,64 & 93,33 & 50,79 & 458,23 & 50,9 \\
\hline
\end{tabular}

Source: see Table 8

An alternative manner to reassume the contribution of each Italian region to tourism sustainability is shown in Figure 5, in which the twenty Italian regions are highlighted in different colours: blue for northern regions; red for central regions; and yellow for southern regions. The first two positions in the road towards tourism sustainability belong to northern regions: Veneto and Lombardia, whilst the last three positions belong to southern regions: Abruzzo, Molise and Basilicata. All central regions lie in the middle of the spectrum. On the whole, the North performs better than the other two large territorial areas.

The information contained in Figure 5 is expressed for size thresholds according to Table 12. Two northern regions (Veneto and Lombardia) and a central region (Lazio) show a high impact on tourism sustainability, whilst only one southern region (Basilicata) records a low contribution to tourism sustainable development. The remaining regions fall between these two polar situations. 
Figure 5. Ranking of the Italian regions using the $Z_{i}$ indicator

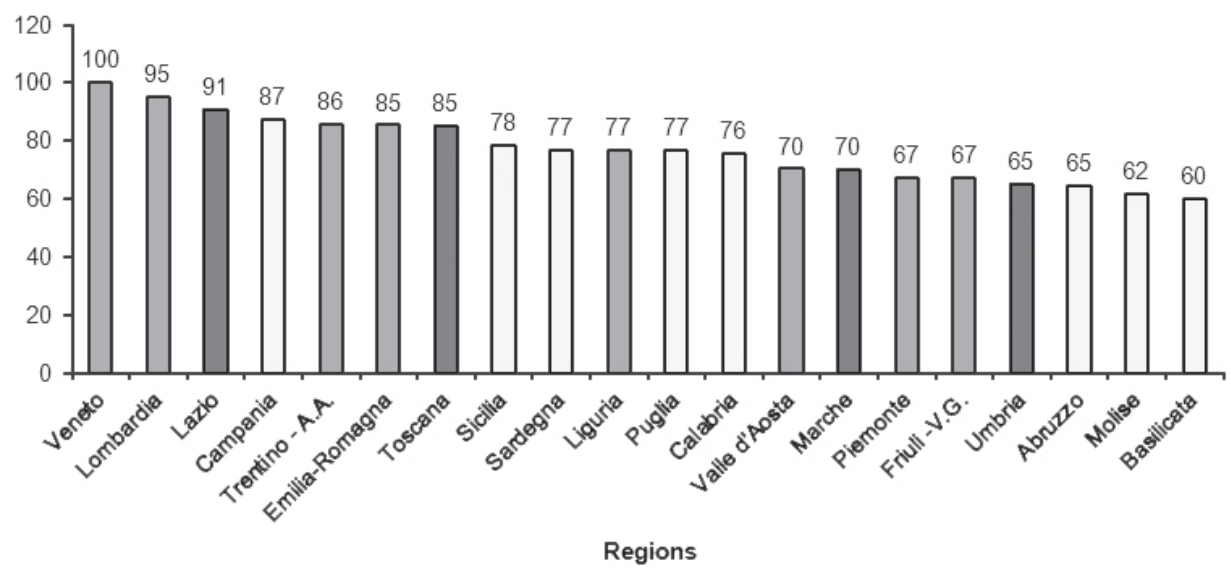

Table 12. $Z_{i}$ index for size thresholds on regional scale in Italy

\begin{tabular}{|l|c|c|}
\hline Size thresholds & $\begin{array}{c}\text { Impact on tourism } \\
\text { sustainability }\end{array}$ & Regions \\
\hline $0 \leq Z \leq 60$ & low & Basilicata \\
\hline $60<Z \leq 70$ & modest & $\begin{array}{c}\text { Valle d'Aosta, Marche, Piemonte, } \\
\text { Friuli - V.G., Umbria, Abruzzo, Molise }\end{array}$ \\
\hline $70<Z \leq 80$ & satisfactory & $\begin{array}{r}\text { Sicilia, Sardegna, Liguria, Puglia, } \\
\text { Calabria }\end{array}$ \\
\hline $80<Z \leq 90$ & good & $\begin{array}{c}\text { Campania, Trentino -A.A., Emilia- } \\
\text { Romagna, Toscana }\end{array}$ \\
\hline $90<Z \leq 100$ & high & Veneto, Lombardia, Lazio \\
\hline
\end{tabular}




\section{Regional tourism destinations}

In this paper we have shown the road to tourism sustainability addressing our considerations to the Italian decentralized situation, and hence to provinces and regions.

Obviously, the fact that our research refers to areas defined by their "administrative" boundaries does not exclude that other territorial dimensions could represent adequate territories to examine the path towards sustainable tourism development as well. Effectively, in other analyses the issue was fruitfully mapped out referring to "regions" with the term exceeding the traditional administrative perspective. Examples of this approach are numerous.

One example of this different approach can be seen in Azerbaijan, where major surveys of sustainable tourism were carried out with reference to the ten economic regions into which the country is divided, as while these regions may have no administrative power, they are relevant in terms of statistics and economic development. In this vein of inquiry falls, for instance, the study assessing tourism potential of the Sheki-Zagatala region. The assessment, after illustrating tourism's importance as an economic activity, pointed out Sheki-Zagatala's tourism needs, also supplying recommendations for future development "by supporting efforts to protect the natural environment and preserve historical attractions, two key competitive advantages for this region" (ULUCHAY, 2014, p. 4). Moreover, Sheki-Zagatala and two other economic regions, Astara-Lankaran and Absheron, were at the heart of a project aimed at creating rural businesses and services in order to attract tourists in these areas. This project, implemented in 2012-2014, raised several challenges, many issues of development in rural tourism were identified, and participation was considered crucial for the long-term future of eco-cultural tourism through the involvement of various stakeholders from small-scale entrepreneurs to national authorities (Heikkilä, Poladova \& Kääriä, 2014). In the same perspective, based on a recent "smart region" paradigm (Garau, 2014), the territory of Mormilla on Italy's island of Sardegna, comprising 18 communes, was chosen as a case study to highlight how the development of sustainable rural tourism can indeed represent an important tool for strengthening and revitalizing lands that would otherwise not be competitive (Garau, 2015).

In other analyses, the path to tourism sustainability has been shown with regard to those regions where there are countries which have features and values that are completely different and which are not only the setting within which 
tourism and impacts occur, but also define the opportunities and constraints for accomplishing sustainability. Among these "typical" economic regions fall, for example, the Mediterranean region, which represents the world's most visited region, hosting around one-third of all international tourists and, at the same time, one of the most fragile territories on the planet (Gordon, 2003; Farsari, Butler \& Prastacos, 2007; IUCN, 2010; Eurostat, 2015). Since the different countries placed along the Mediterranean Sea greatly differ in terms of their environmental, socio-cultural, political and economic characteristics, tourism destination management in the area will call for a necessary compromise of the different interests and views of the various nations to work together towards a common goal to ensure not only the viability and integrity of their own tourism destinations but, above all, the sustainability and competitiveness of a much wider territory, namely, the Mediterranean Sea itself (UNEP, 2005). Clearly, the considerations made with regard to the world's most visited region can, with the necessary adjustments, be applied to all types of region including those which, while physically small, in any case offer a particular tourism experience. On the whole, tourist regions made up of different countries will have at one end of the continuum the Mediterranean Sea, followed by other, less extensive, territorial areas such as, for example, the Caribbean region (Wilard, 2011), the Baltic region (Günther, 2011; Emmelin, 2006), the Alps region (Secretariat of the Alpine Convention, 2013), the Carpathian region (Kondur, Kopchak \& Kopchak, 2014), the Asian and Pacific regions (UN, 2001), while at the other end of the spectrum there will be very small territories seen by visitors as places fit for one overnight stay ${ }^{16}$.

It is worth drawing attention to those regions whose distinctive feature is not their size but rather whose appeal is constituted by their unique environmental setting. This is the case of the polar regions. The Arctic and the Antarctic are among the world's coldest places, and contain most of the of the world's ice and snow. During the past two centuries, tourism has grown to become the single largest human presence in these areas, and visitors to these territories

16 Good examples of how tourism sustainability applies to small regional tourism destinations are provided by Carson and Macbeth (2005). As for Australia and New Zealand, they discuss eleven case studies referred to many different types of destinations and many different forms of tourism. Of these destinations, some were founded on administrative boundaries and tourism management regions while others reflected historical community. Some cases were smaller than a single government area, while others spanned boundaries of up to seven local governments. The differences in destinations, therefore, appeared to be in terms of scale rather than in terms of fundamental organization and management of destinations, jointly aimed at enhancing the economic, social and environmental benefits of tourism while minimizing its potential negative impacts. 
now greatly exceed their host population in many popular destinations, with the Russian Arctic and part of the Canadian Arctic as noticeable examples of this picture. Given tourism's relevance in both polar regions, and the expected likelihood that it will continue to expand, the search for sustainable tourism policies has become more insistent and important studies now exist to determine the significance of polar tourism and the vulnerability of the polar environment (Stewart, Drape \& Johnston, 2005; Lück, Maher \& Stewart, 2010).

Finally, in other analyses the concept of region has embraced territories which are defined in terms of the particular aspects of this or that "economic good" from which local communities derive jobs, income and business revenues, not only in relation to the production of the economic good but also in the light of the flow of tourists prompted by visits to the places where the production arises. Since wine surely has a firm place among these economic goods, wine tourism is now being developed in many regions of the world (e.g., the Chianti and the Barbera region in Italy, and the Beaujolais region in France), the meaning and elements of sustainable wine tourism from the regional perspective have been developed, and many papers now supply a literature review, an examination of case studies and also a fruitful framework for strategic planning and management of the wine tourism industry (Carlsen, 2004; Buchmann, 2009; Poitras \& Getz, 2010; Carmichael \& Senise, 2011; Alonso \& Liu, 2012; Santini, Cavicchi \& Casini, 2013; Peris-Ortiz, DelRio Rama \& Rueda-Armengot, 2016).

It goes without saying that all the mentioned analyses fall within the generally accepted concept of 'tourism destination', which refers to "an area of visitor appeal which includes accommodation, attractions and support services. It may be defined by physical, thematic or administrative boundaries and it embraces a set of distinctive images and qualities that give it a brand identity" (Tourism Sustainability Group, 2007, p. 18) ${ }^{17}$.

17 The UNWTO (2007, p. 1) supplied a specification of this view giving a more precise definition of a 'tourism destination' according to which the concept has to refer to "a physical space in which a tourist spends at least one an overnight stay [...]. It has physical and administrative boundaries defining its management, and images and perceptions defining its market competitiveness". 


\section{Concluding remarks}

While the movement towards sustainable tourism gained impetus in the early 1990s with the publication of the Brundtland report, there was no universally acknowledged approach towards tourism sustainability until 2005 when the UNEP, together with the UNWTO, developed a set of principles and aims addressing economic, environmental and social impacts and effects of the hospitality industry. On the whole, this approach pointed out that developing an evaluation framework of tourism and development policy was a very powerful and positive method to demonstrate whether and to which extent tourism sustainability was effectively reached. In this direction, the identification of indicators linked to sustainability objectives, and a continuous process of regular monitoring against them, was seen as "a critical component of destination management if it is truly to embrace sustainability" (Tourism Sustainability Group, 2007, p. 21).

In order to serve the dual function of providing a basis for improving the efficiency of planning and programming, and a tool to verify achievements against intended results in tourism sustainability, five criteria for the selection of indicators to be included in the evaluation framework were identified:

- Relevance of the indicator to the selected question;

- Feasibility of acquiring and analysing the information required;

- Credibility and reliability of the collected data;

- Clarity and ease of understanding amongst all key stakeholders of the strategic choice of tourism policy formulation;

- Comparability over time and across tourism destinations.

In gaining clear and reliable feedback following the implementation of measures and actions in the road to tourism sustainability, the EU was also working on the individuation of an indicator set for the allocation of resources and the demonstration of outcomes for each of the agreed development objectives; in this direction, at the end of 2004, the European Commission launched the Tourism Sustainability Group (TGS), which commenced working in 2005.

From this joint effort a wide indicator set for tourism destinations flourished. Some of these indicators were seen as both fundamental to sustainability and relatively easy to gather, while of other indexes of this list the need for their collection was outlined as being directly relevant to the issue of tourism sustainability since they would enable the question to be framed more accordingly. 
Our research is sufficiently consistent with the overall context outlined. The research has used data coming exclusively from the annual census survey collecting the main structural information regarding the accommodation establishments in Italy. Moreover, the indexes elaborated from these data can be easily understood by local authorities, governments, development managers and other key actors involved in tourism sustainability. The comparability of the indexes over time and across tourism destinations is ensured as well. Some critical issues could be raised on the relevance of the indexes to the main features of tourism sustainability. After saying that the list of the indicators utilized is far from being exhaustive, the relevance and the capacity of the indexes showing the peculiar aspects of the hotel supply could be questioned with reference to the index $N$, which is the index of comfort of hotel establishments, according to which "the greater the index is, the more comfortable is the tourist experience and hence the higher customer satisfaction". So, dividing bathrooms in region (province) with rooms in region (province) and multiplying it by 100 we would quantify the index. We are conscious that it is not enough to use only one measure to express the whole spectrum of comfort associated with nights spent in tourist accommodation establishments in any destination, as this parameter of the supply side of the tourist market is effectively linked to a wide range of elements that will determine the visitors' decision to make their journey. ${ }^{18}$

Amongst the additional elements which surely exert influence on the destination appeal and visitor satisfaction are, for instance, the relative social inclusion of establishments, the establishments' ability to provide a visitor experience without discrimination, the presence of an establishment management able to meet the variegated visitors' exigencies, and so on. In order to capture these aspects of tourism destination other indexes are thus necessary, such as the following:

- Percentage of visitors indicating suggestions of appropriate measure to enhance the pleasantness of the stay;

18 Given the overall aim of our research to examine the development that tourism has registered in Sicily as a consequence of the public intervention progressively implemented since the $1920 \mathrm{~s}$, the utility of the $N$ indicator is straightforward. Using this indicator allows us to assess the impact state intervention has upon different facets of what the tourism sector offers across a significant time frame. With this goal in mind, our research has shown how, compared to the situation as it was in the early post-Second World War years, the $N$ indicator has increased by a significantly greater degree in the southern regions of the country than in the Centre-North, and that Sicily, in comparison with the poor data for the South, was, before the extraordinary intervention scheme for the Mezzogiorno, in second place for indicator $N$, just behind Campania. 
- Percentage of visitors indicating that they are fully satisfied with overall experience;

- Percentage of visitors who are on a repeat visit and percentage of those who say they will return;

- Percentage of tourism establishments meeting specified accessibility standards;

- Percentage of visitors who benefit from some supported holiday scheme;

- Percentage of visitors with a physical or sensory disability saying proposals to make their visit more comfortable;

- Percentage of hotels with rooms accessible to persons with disabilities;

- Percentage of access doors to buildings which have automated openers or attendants on the door;

- Percentage of restaurants and hotels with wheelchair accessible restrooms.

Since these indicators are not usually collected by the official statistics on the capacity and occupancy of tourism accommodation establishments, they would rely on specific surveys of visitors and tourism enterprises. Surveys of this kind have the advantage of being immediately better associated with the particular issue. However, they could be costly and time-consuming. Thus, the availability of indicators, and the practicability and cost of estimating them should be carefully considered both in identifying suitable indexes and in determining the most cost-effective way of measuring them. Furthermore, the estimation of these additional indicators would have to follow from the adoption of the same equivalent method in each destination; otherwise, the chosen indicators could not be used for benchmarking by supplying an unbiased picture. This is a significant limitation.

Another consideration regards the adequacy of our attempt to identify a balanced indicator showing the impact of tourist-accommodation facilities and related infrastructure in Sicily and in the other Italian regions in terms of the three fundamental pillars of sustainability. The thrust of our research is to make a contribution to the field, as the body of literature is currently more concerned with drawing up lists of indicators for tourism sustainability in destinations rather than investigating the possibility of producing a single measure to understand how the implementation of policies and actions effectively impact on tourism sustainability in such a way to permit an immediate comparison with other destinations.

On the other hand, developing an evaluation framework of tourism and local development policy according to the approach adopted in this paper seems to 
be the usual practice in many experiences registered at decentralized level in Italy. A good example of this view is supplied by the attempt supplied by Puglia, a southern Italian region, through the implementation of the OECD LEED Project on Sustainable Tourism and Local Development in the Apulia region. In this project, aimed at assisting the regional government and its regional and sub-regional partners to review policies and assets of the region so as to introduce more effective sustainable tourism development, evaluation was seen not as "an option or a bureaucratic tick box exercise" but rather as "a critical component of policy-making in all sectors and at levels" in order to increase the competitiveness of Puglia as a destination and "facilitate the seasonal adjustments of the local tourism industry" (OECD, 2010, p. 98). By the same token, in Calabria, another southern region, the Regional Plan for Sustainable Tourism Development 2011-2013 illustrated "an exercise for evaluating the environmental, social and economic impacts of tourism" (Consiglio regionale della Calabria, 2011, p. 33), with such impacts being measured by means of a set of indicators in line with those utilized in our analysis. ${ }^{19}$

In conclusion, within the wide range of experiences registered at decentralized level in the field of tourism sustainability in Italy, the road towards this type of development shows that a great effort is currently to be made to individuate an evaluation framework for tourism that features a clearly outlined set of indicators to be measured in accordance with specific agreed-upon development objectives and goals. In this perspective, our research aims to contribute to establishing, implementing and monitoring successful sustainable tourism development at local level. Obviously, as with all similar attempts, our own effort shows "lights and shadows". It is our hope that the "lights" will outshine the "shadows" and that the growing awareness of their positive consequences will allow the refinement of the proposed methodology.

Silvana Cassar is associate professor of economic history at the Department of Economics and Business, University of Catania. She has authored several essays and two monographs on Sicilian economy. She is also the co-author of several papers on particular aspects of Italian economy.

Salvo Creaco is professor of public finance at the Department of Economics and Business, University of Catania. His fields of research are local finance, public choice theory, tourism economics, environmental economics and sustainable development theory.

19 The practical implementation of this approach is provided by Avena and Giacalone (2011). 


\section{References}

Alonso, A. D. \& Liu, Y. (2012), “Old wine region, new concept and sustainable development: winery entrepreneurs' perceived benefits from wine tourism on Spain's Canary Islands,' Journal of Sustainable Tourism, vol. 20, no. 7, pp. 991-1009. http://dx.doi.org/10.1080/09669582.2011.651220

Alvarez, M. D. (2014), 'Sustainability issues: Tourism as an instrument for development,' in E. Fayos-Solà, M. D. Alvarez \& C. Cooper (eds.) Tourism as an Instrument for Development: A Theoretical and Practical Study, Bingley: Emerald, pp. 87-100. http://dx.doi.org/10.1108/s2042-144320140000006001

Avena, G. \& Giacalone, M. (2011), “Un'analisi statistica del turismo sostenibile in Calabria,", Rivista di scienze del turismo, vol. 3, pp. 27-35.

Barbier, E. B. (1998), The Economics of Environment and Development: Selected Essays, London: Edward Elgar.

BarOn, R. R. V. (1973), 'Seasonality in tourism - Part II,' International Tourism Quarterly, vol. 1, pp. 51-67.

- (1975), Seasonality in Tourism: A Guide to the Analysis of Seasonality and Trends for Policy Making, London: The Economist Intelligence Unit Limited.

Barney, G. O. (1980), The Global 2000 Report to the President of the U.S., Washington, DC: U.S. Government Printing Office.

Baum, T. \& Lundtorp, S., eds. (2011), Seasonality in Tourism. Amsterdam: Elsevier.

Beltratti, A.; Chichilnisky, G. \& Heal, G. (1993), Sustainable Growth and the Green Golden Rule, NBER Working Paper no. 4430, Cambridge: National Bureau of Economic Research. http://dx.doi.org/10.3386/w4430

Berno, T. \& Bricker, K. (2001), 'Sustainable tourism development: The long road from theory to practice,' International Journal of Economic Development, vol. 3, no. 3, pp. 1-18.

Blaug M. (1978), Economic Theory in Retrospect, Cambridge: Cambridge University Press.

Boyer, J. C. (1972), Le tourisme, Paris: Éd. du Seuil.

Bresso, M. (1982), Pensiero economico e ambiente, Torino: Loescher Editore. (1993), Per un'economia ecologica, Roma: La Nuova Italia Scientifica.

Buchmann, A. (2009), 'Managing sustainable wine tourism industry,' Wine Business Research Symposium Proceedings, University of Newcastle, pp. 250-263.

Buckley, R. (2012), 'Sustainable tourism: Research and reality,' Annals of Tourism Research, vol. 39, no. 2, pp. 528-546. http://dx.doi.org/10.1016/j. annals.2012.02.003

Butler, R. (1994), 'Seasonality in tourism: issues and problems,' in A. V. Seaton (ed.) Tourism: The State of the Art, New York: John Wiley \& Sons, pp. 332-339. 
Byrd, E. T. (2007), 'Stakeholders in sustainable tourism development and their roles: applying stakeholder theory to sustainable tourism development,' Tourism Review, vol. 62, no. 2, pp. 6-13. http://dx.doi.org/10.1108/16605370780000309

Cannas, R. (2012), 'An overview of tourism seasonality: key concepts and policies,' Alma Tourism, vol. 5, pp. 40-58.

Carlsen, J. (2004), 'A review of global wine tourism research,' Journal of Wine Research, vol. 15, no. 1, pp. 5-13. http://dx.doi.org/10.1080/0957126042000300281

Carmichael, B. A. \& Senise, D. M. (2011), 'Competitiveness and sustainability in wine tourism regions: the application of a stage model of destination development to two Canadians wine regions,' in P. H. Dougherty (ed.) The Geography of Wine: Regions, Terroir and Techniques, Berlin: Springer, pp. 159-178.

Carson, D. \& Macbeth, J., eds. (2005), Regional Tourism Studies. Innovation on Regional Tourism, Altona Victoria: Common Ground Publishing.

Cassar, S. (2007), 'Tourism development in Sicily during the fascist period (19221943), Journal of Tourism History, vol. 1, no. 2, pp. 131-149. http://dx.doi.org/10.1080/17551820903353447

(2015a), 'Il settore turistico in Sicilia nella seconda metà del Novecento,' in P. Folguera et al. (eds.) Pensar con la historia desde el siglo XXI, Actas del XII Congreso de la Asociación de Historia Contemporánea, Madrid: UAM Ediciones, pp. $457-477$.

— (2015b), 'Offerta ricettiva e flussi turistici in Sicilia,' in P. Avallone \& D. Strangio (eds.) Turismi e turisti. Politica, innovazione, economia in Italia in età contemporanea, Milano: FrancoAngeli, pp. 137-180.

Cassar, S. \& Creaco, S. (2012), 'Il ruolo della Cassa per il Mezzogiorno nello sviluppo del settore turistico,' Rivista Economica del Mezzogiorno, vol. XXVI, no. 3, pp. 521-556.

Cavallo, L. \& Santoro, M. T. (2014), 'The seasonal adjustment of occupancy variables: the Italian experience,' Paper delivered at the 2nd Global Forum on Tourism Statistics, May 14-17, Prague.

Cerina, F.; Markandya, A. \& McAleer, M., eds. (2010), Economics of Sustainable Tourism, New York: Routledge.

Cernat, L. \& Gourdon, J. (2007), Is the Concept of Sustainable Tourism Sustainable? New York: United Nations.

Chichilnisky, G. (1977a), 'Development patterns and the international order,' Journal of International Affairs, vol. 32, no. 2, pp. 275-304. http://dx.doi.org/10.2139/ ssrn. 1366878

(1977b), 'Economic development and the efficiency criteria in the satisfaction of basic needs,' Applied Mathematical Modelling, vol. 1, pp. 290-298. http://dx.doi. org/10.1016/0307-904X(77)90060-9 
Choi, H. C. \& Sirakaya E. (2006), 'Sustainable indicators for managing community tourism,' Tourism Management, vol. 27, pp. 1274-1289. http://dx.doi. org/10.1016/j.tourman.2005.05.018

Chung, J. C. (2009), 'Seasonality in tourism: A review,' E-Review of Tourism Research, vol. 7, no. 5, pp. 82-96.

Ciani Scarnicci, M.; Marcelli, A.; Pinelli, P.; Romani, A. \& Russo, R. (2014), Economia, ambiente e sviluppo sostenibile, Milano: FrancoAngeli.

Cobbinah, P. B.; Black, R. \& Thwaites, R. (2013), 'Tourism planning in developing countries: review of concepts and sustainable issues,' International Journal of Social Education, Economics and Management Engineering, vol. 7, no. 4, pp. $468-475$.

Consiglio regionale della Calabria (2011), Approvazione del Piano regionale di sviluppo turistico sostenibile per il triennio 2011-2013, Reggio di Calabria.

Cooper, C.; Wanhill, S.; Fletcher, J.; Gilbert, D. \& Fyall, A. (2008), Tourism: Principles and Practice, Harlow: Pearson Education.

Creaco, S. (2015a), 'Turismo e intervento straordinario per le aree depresse in Italia,' in P. Folguera et al. (eds.) Pensar con la historia desde el siglo XXI, Actas del XII Congreso de la Asociación de Historia Contemporánea, Madrid: UAM Ediciones, pp. 425-456.

(2015b), 'Turismo e intervento straordinario nel Mezzogiorno,' in P. Avallone \& D. Strangio (eds.) Turismi e turisti. Politica, innovazione, economia in Italia in età contemporanea, Milano: FrancoAngeli, pp. 93-136.

Defert, P. (1966), Le tourisme, factor de valorisation régionale, Paris: Centre de recherches économiques et sociales.

(1967), La taux de fonction touristique: mise en point et critique, Aix-en-Provence: Centre d'études du tourisme.

Diaz, D. (2011), 'The viability and sustainability of international tourism in developing countries,' Paper delivered at the Symposium on Tourism Services, Geneva.

Dixon, J. A. \& Steer, A., eds. (1994), The World Bank and the Environment: A Fourfold Agenda, Washington, DC: The World Bank.

EC (1992), Towards Sustainability, A European community programme for policy and action in relation to the environment and sustainable development. Official Journal of the European Communities, C 138/5, 17.05.1993.

Emmelin, L. (2006), Sustainable Tourism Development in the Baltic Sea Region, Östersund: The European Tourism Research Institute.

Eurostat (2015), Tourism Statistics at Regional Level, Brussels.

Farsari, Y.; Butler, R. \& Prastacos, P. (2007), 'Sustainable tourism policy for Mediterranean destinations: issues and interrelationships,' International Journal of Tourism Policy, vol. 18, no. 1, pp. 58-78. http://dx.doi.org/10.1504/ IJTP.2007.013898 
Fossati, A. \& Panella, G., eds. (2000), Tourism and Sustainable Economic Development, Dordrecht: Kluwer Academic Publishers.

Garau, C. (2014), 'Smart paths for advanced management of cultural heritage,' Regional Studies, Regional Science, vol. 1, no. 1, pp. 286-293. http://dx.doi.org/10.1080/21 681376.2014 .973439

- (2015), 'Perspectives on cultural and sustainable rural tourism in a smart region: the case study of Marmilla in Sardinia (Italy), Sustainability, vol. 7, no. 6, pp. 6412-6434. http://dx.doi.org/10.3390/su7066412

Giacalone, M.; La Tona, L. \& Marino, C. (2005), Sustainability in the ReceptiveTourist Field in Sicily, Relazione al Convegno SIS: Statistics and Environment, Università di Messina.

Gordon, B. M. (2003), 'The Mediterranean destination from classical antiquity to Club Med,' Mediterranean Studies, vol. 12, pp. 203-226.

Grafton, R. Q.; Adamowicz, W.; Dupont, D.; Nelson, H.; Hill, R. J. \& Renzetti, S. (2004), The Economics of the Environment and Natural Resources, Oxford: Blackwell Publishing. http://dx.doi.org/10.1002/9780470755464

Günther, W. (2011), Sustainable Tourism Development in the Baltic Sea Region, Kiel: Institute for Tourism Research in Northern Europe.

Heal, G. M. (1998), 'Interpreting sustainability,' in G. Chichilnisky, G. M. Heal \& A. Vercelli (eds.) Sustainability: Dynamics and Uncertainty, Dordrecht: Kluwer Academic Publishers. http://dx.doi.org/10.1007/978-94-011-4892-4_1

Heikkilä, J.; Poladova, A. \& Kääriä, J. (2014), 'Need for service design development for sustainable rural tourism in Azerbaijan,' Baltic Journal of European Studies, vol. 4, no. 2, pp. 83-98. http://dx.doi.org/10.2478/bjes-2014-0017

Herrera, A. O. (1974), Introduction and basic assumptions of the model, Proceedings of the second IIASA symposium on global modelling, Laxenburg: International Institute for Applied Systems Analysis, pp. 3-8.

Herrera, A. O.; Scolnik, H. D. \& Chichilnisky, G. (1976), Catastrophe or New Society. A Latin American World Model, Ottawa: International Development Research Centre.

Istituto centrale di statistica (2013), Annuario statistico italiano. Anno 2013, Roma.

_ (2014a), La superficie dei comuni, delle provincie e delle regioni italiani, Roma. (2014b), Statistiche del turismo. Anno 2013, Roma.

IUCN (2010), Sustainable Tourism in the Mediterranean Panorama and Perspectives, Strategies and Actions, Gland: IUCN.

IUCN; UNEP \& WWF (1980), World Conservation Strategy: Living Resource Conservation for Sustainable Development, Gland: IUCN, UNEP \& WWF.

Kondur, O.; Kopchak, Y. \& Kopchak, L. (2014), 'Role of the tourism sector in sustainable development of the Carpathian region: social, educational and economic aspects,' Journal of Vasyl Stefanyk Precarpathian National University, 
vol. 1, nos. 2-3, pp. 119-122. http://dx.doi.org/10.15330/jpnu.1.2-3.119-122

Liu, Z. (2003), 'Sustainable tourism development: a critique,' Journal of Sustainable Tourism, vol. 11, no. 6, pp.459-475.http://dx.doi.org/10.1080/09669580308667216

Lück, M.; Maher, P. T. \& Stewart, E. J., eds. (2010), Cruise Tourism in Polar Regions: Promoting Environmental and Social Sustainability? London: Routledge.

Manning, T. (1999), 'Indicators of tourism sustainability,' Tourism Management, vol. 20, pp. 179-181.

Markandya, A.; Taylor, T. \& Pedroso, S. (2003), 'Tourism and sustainable development: Lessons from recent World Bank experience,' Paper delivered at the International Conference on Tourism and Sustainable Economic Development, Macro e micro issues, Chia (Cagliari).

Meadows, D. H.; Meadows, D. L.; Randers, J. \& Behrens, W. W. (1972), The Limits to Growth, New York: Universe Books.

Middleton, V. T. C. \& Hawkins, R. (1998), Sustainable Tourism: A Marketing Perspective, Oxford: Butterworth-Heinemann.

Milne, S. (1998), 'Tourism and sustainable development: Exploring the global-local nexus,' in C. M. Hall \& A. A. Lee (eds.) Greening the Sustainable Tourism: A Geographical Perspective, Essex: Longman, pp. 35-48.

Mirloup, J. (1974), 'Élements méthodologiques pour une étude de l'équipment hôtelier: l'exemple des departments de la Loire moyenne,' Norois, vol. 4, no. 1, pp. 563-583. http://dx.doi.org/10.3406/noroi.1974.3404

Musu, I. (1993), Economia e ambiente, Bologna: Il Mulino.

O’Mahony, B. \& McMurray, A. (2008), Seasonality in the Tourism Industry: Impacts and Strategies, Gold Coast: Sustainable Tourism Cooperative Research Centre's Monograph Series.

O'Riordan, T. (1993), 'The politics of sustainability,' in R. K. Turner (ed.) Sustainable Environmental Economics and Management: Principles and Practice, New York: John Wiley \& Sons, pp. 37-69.

OECD (2010), Sustainable Tourism and Local Development in Apulia Region, Paris: OECD.

Osservatorio turistico della Regione siciliana (2005), Il turismo in Sicilia. I flussi dell'incoming nazionali ed internazionali. 2004-2005, Palermo.

- (2013), Il turismo in Sicilia. Rapporto 2012-2013, Palermo.

(2014), Piano strategico di sviluppo turistico 2014-2020, Programma triennale 2015-2017, Palermo.

Özçevik, O.; Brebbia, C. A. \& Şener, S. M. (2015), Sustainable Development and Planning VII, Southampton: The WIT Press.

Pearce, D. (2002), 'An intellectual history of environmental history,' Annual Review of Energy and the Environment, vol. 27, pp. 57-81. http://dx.doi.org/10.1146/ annurev.energy.27.122001.083429 
Pearce, D. W. \& Turner, R. K. (1990), Economics of Natural Resources and the Environment, New York: Harvester Wheatsheaf.

Peris-Ortiz, M.; DelRio Rama, M. \& Rueda-Armengot, C. (2016), Wine and Tourism: A Strategic Segment for Sustainable Economic Development, Berlin: Springer. http://dx.doi.org/10.1007/978-3-319-18857-7

Petreska, B. (2013), 'Empirical analysis of seasonality in tourism patterns,' Journal of Process Management, vol. 1, no. 2, pp. 87-95.

Pezzey, J. (1989), Definitions of Sustainability, Working Paper no. 9, London: UK Centre for Environment and Development.

_ (1997), 'Sustainability constraints versus "optimality" versus intertemporal concern, and axioms versus data,' Land Economics, vol. 73, no. 4, pp. 448-466. http://dx.doi.org/10.2307/3147239

Poitras, L. \& Getz, D. (2010), 'Sustainable wine tourism: the host community perspective,' Journal of Sustainable Tourism, vol. 14, no. 5, pp. 425-448. http:// dx.doi.org/10.2167/jost587.0

Presidenza del Consiglio dei Ministri (2013), Turismo Italia 2020. Piano strategico per lo sviluppo del turismo in Italia, Roma.

Sandmo, A. (2014), The Early History of Environmental Economics, Bergen: Norwegian School of Economics.

Santini, C.; Cavicchi, A. \& Casini, L. (2013), 'Sustainability in the wine industry: Key questions and research trends,' Agricultural and Food Economics, vol. 1, pp. 1-14. http://dx.doi.org/10.1186/2193-7532-1-9

Secretariat of the Alpine Convention (2013), Sustainable Tourism in the Alps. Report on the State of the Alps, Innsbruck: Secretariat of the Alpine Convention.

Shah, K.; McHarry, J. \& Gardiner, R. (2002), 'Sustainable tourism - turning the tide, towards Earth Summit 2002,' Economic Briefing, vol. 4, pp. 1-14.

Sharpley, R. (2000), 'Tourism and sustainable development: exploring the theoretical divide,' Journal of Sustainable Tourism, vol. 8, no. 1, pp. 1-19. http://dx.doi. org/10.1080/09669580008667346

Sirageldin, I. (1994), 'Making development sustainable,' in I. Sirageldin \& A. Steer (eds.) Making Development Sustainable: From Concepts to Action, Environmental Sustainable Development Occasional Papers, no. 2, Washington, DC: World Bank. http://dx.doi.org/10.1596/0-8213-3042-X

Solow, R. (1993), 'An almost practical step toward sustainability,' Resources Policy, vol. 19, no. 3, pp. 162-172. http://dx.doi.org/10.1016/0301-4207(93)90001-4

Stewart, E. J.; Drape. D. \& Johnston (2005), 'A review of tourism research in the polar regions,' Arctic, vol. 58, no. 4, pp. 383-394.

Swarbrooke, J. (1999), Sustainable Tourism Management, New York: CABI Publishing.

Tanguay, G. A.; Rajaonson, J. \& Therrien, M-C. (2011), Sustainable Tourism Indicators: Selection criteria for policy implementation and scientific recognition, 
Montréal: Centre Interuniversitaire de Recherche en Analyse des Organisations (CIRANO).

Tourism Sustainability Group (2007), Action for More Sustainable Tourism, Brussels: European Commission.

Turner, R. K. (1993), 'Sustainability: principles and practice,' in R. K. Turner (ed.) Sustainable Environmental Economics and Management: Principles and Practice, New York: John Wiley \& Sons, pp. 3-36.

ULUCHAY (2014), Sheki-Zagatala Economic Region: Assessing Tourism Potential, Sheki: ULUCHAY.

UN (1972), Report of the United Nations Conference on the Human Environment, New York: United Nations.

- (2001), Plan of Action for Sustainable Tourism Development in the Asian and Pacific Region (1999-2005), New York: United Nations.

(2002), Report of the World Summit on Sustainable Development, New York: United Nations.

UNEP (2005), Mediterranean Strategy for Sustainable Development: A Framework for Environmental Sustainability and Shared Prosperity, Athens: UNEP.

UNEP \& UNWTO (2005), Making Tourism More Sustainable: A Guide for Policy Makers, Paris: UNEP \& UNWTO.

UNWTO (2006), What Tourism Managers Need to Know: A Practical Guide to the Development and Use of Indicators of Sustainable Tourism, Madrid: UNWTO. (2007), A Practical Guide to Tourism Destination Management, Madrid: UNWTO.

Waligo, V. M.; Clarke, J. \& Hawkins, R. (2013), 'Implementing sustainable tourism: a multi-stakeholder involvement management framework,' Tourism Management, vol. 36, pp. 342-353. http://dx.doi.org/10.1016/j.tourman.2012.10.008

Wall, G. \& Mathieson, A. (2006), Tourism: Change, Impacts and Opportunities, Edinburgh: Pearson Education.

Weaver, D. \& Lawton, L. (1999), Sustainable Tourism: A Critical Analysis, Gold Coast: CRC.

Wilard, P. (2011), Regional Environmental Policy and Sustainable Tourism Development in the Caribbean, Santiago: United Nations Publication.

World Commission on Environment and Development (1987), Our Common Future, London: Oxford University Press.

WTO (1993), Indicators for the Sustainable Management of Tourism, Madrid: WTO.

- (1997), What Tourism Managers Need to Know: A Practical Guide to the Development and Use of Indicators of Sustainable Tourism, Madrid: WTO.

_ (1998), Guide for Local Authorities in Developing Sustainable Tourism, Madrid: WTO.

_ (1999), Sustainable Development of Tourism: An Annotated Bibliography, Madrid: WTO. 
— (2004), Indicators of Sustainable Development for Tourism Destinations: A Guidebook, Madrid: WTO.

Yazdi, S. (2012), 'Sustainable tourism,' American International Journal of Social Science, vol. 1, no. 1, pp. 50-56.

Yunis, E. (2004), 'Indicators to measure sustainability in tourism,' Paper delivered at the 7th International Forum on Tourism Statistics. Stockholm, 9-11 June. 